\title{
WestVirginiaUniversity
}

THE RESEARCH REPOSITORY @ WVU

Graduate Theses, Dissertations, and Problem Reports

2012

\section{Essays on the Economics of Student Achievement}

Amy F. Higginbotham Godfrey

West Virginia University

Follow this and additional works at: https://researchrepository.wvu.edu/etd

\section{Recommended Citation}

Godfrey, Amy F. Higginbotham, "Essays on the Economics of Student Achievement" (2012). Graduate Theses, Dissertations, and Problem Reports. 624.

https://researchrepository.wvu.edu/etd/624

This Dissertation is protected by copyright and/or related rights. It has been brought to you by the The Research Repository @ WVU with permission from the rights-holder(s). You are free to use this Dissertation in any way that is permitted by the copyright and related rights legislation that applies to your use. For other uses you must obtain permission from the rights-holder(s) directly, unless additional rights are indicated by a Creative Commons license in the record and/ or on the work itself. This Dissertation has been accepted for inclusion in WVU Graduate Theses, Dissertations, and Problem Reports collection by an authorized administrator of The Research Repository @ WVU.

For more information, please contact researchrepository@mail.wvu.edu. 


\title{
Essays on the Economics of Student Achievement
}

\author{
Amy F (Higginbotham) Godfrey \\ Dissertation submitted to the \\ Department of Economics \\ College of Business and Economics \\ West Virginia University \\ In partial fulfillment of the requirements for \\ the degree of \\ Doctor of Philosophy \\ in \\ Economics
}
Santiago Pinto, Ph.D., chair
Tami Gurley-Calvez, Ph.D.
George Hammond, Ph.D.
Brian Cushing, Ph.D.
Strat Douglas, Ph.D.

Morgantown, WV

2012

Keywords: student achievement, public education finance, gender, excess levies

Copyright 2012 Amy F Godfrey 
Page is intended to be Blank 


\title{
ABSTRACT \\ Essays on the Economics of Student Achievement
}

\author{
Amy F Godfrey
}

Parents, lawmakers, and economists are all keenly interested in what affects student performance. This dissertation explores factors influencing student achievement in West Virginia with special attention devoted to public education resources and gender. Politicians and many parents of school age children believe increased levels of education funding or resources result in higher student achievement. Chapters 2 and 3 delve into this topic by exploring student achievement at different grade levels in West Virginia. The first public education funding or resource change to be analyzed occurred during a time period when the base for public education financing was expanding and funding levels were converging across school districts in the state. Data is a school-district level panel, including student achievement scores, from 1989 to 2002. The results suggest that rising expenditure levels may have had a positive effect on student achievement especially in areas with below average levels of spending prior to the policy change.

The second public education funding change to be analyzed involves additional instructional or classroom resources from public education excess levies that are voted on by residents in each school district. Results indicate that additional instructional or classroom resources that are unexpected or not relied upon may have a positive impact on student achievement levels at all grade levels. However, the probability of adopting a public education excess levy can be negatively affected in school districts with increasing levels of population in retirement age, less population per square mile, or more households in poverty. 
After analyzing the effect of public education resources, this dissertation explored the impact of gender on academic achievement. For years there has been an argument about who is smarter: men or women. Research on the achievement levels of students in elementary, intermediate, and high school have found that there is a gender gap in the academic performance in mathematics which favors boys. In this chapter, analysis of $5^{\text {th }}$ graders in West Virginia finds the opposite gender gap in mathematics. While girls tend to outperform boys in mathematics from 2003 to 2007, the percentage of girls in each school district was shown to not significantly affect proficiency levels for the entire school district. The mathematical performance levels of boys and girls were found to possibly be influenced by different factors including poor peer performance and classroom size. 


\title{
Table of Contents
}

\author{
Abstract i \\ Table of Contents \\ Chapter 1: Purpose and Agenda 1 \\ 1.1 Introduction \\ 1.2 Effect of School Resources on Different Grade Levels \\ 1.3 Effect of Specific School Resources \\ 1.4 Effect of Gender
}

Chapter 2: Effect of School Resources on Different Grade Levels

2.1 Introduction

2.2 Previous Literature

2.3 Public Education Expenditures

2.4 Effect on Student Achievement

2.5 Conclusion

Chapter 3: How Important Are Excess Levies to Students?

3.1 Introduction

3.2 Determinants of Academic Achievement

3.3 West Virginia Data

3.4 Characteristics of West Virginia Excess Levy School Districts

3.5 Effect of Excess Levy Revenue on Student Achievement

3.6 Conclusion

Chapter 4: Boys Are Better At Math? An Examination of the

Effects of Gender on Student Achievement

64

4.1 Introduction

4.2 Gender Gap in Mathematics

4.3 Data

4.4 Methodology and Results

4.5 Reasons behind Gap in $5^{\text {th }}$ Grade Mathematics in West Virginia 4.6 Conclusion

Chapter 5: Conclusion $\quad 82$

References $\quad 86$ 


\section{Chapter 1: Purpose and Agenda}

\subsection{Introduction}

Student achievement is an important topic for parents, teachers, law makers, researchers, and students alike. Student performance levels in comparison to their peers within their school or school districts, within the state, country, or internationally brings about discussions and research on what factors most effect student achievement. Significant research has been devoted to the influence of school resources, family, peers, health, and gender on achievement.

School resources, which have been measured by expenditures, number of teachers, technology levels, and other school inputs, have been one of the most researched influences of achievement. With the passage of the Civil Rights Act in 1964, analysis of the equal provision of public education funding and its relationship to performance began to be extensively examined. The Coleman report in 1966 found that factors such as family and peers had the most significant impact on student achievement while school resources, measured by class size, had no effect. Hanushek in a review of the literature thirty years later found that the empirical research on this topic published after the Coleman report backed up the conclusions found in 1966.

An educational production function has been adopted by the literature to examine the factors that affect student achievement (Equation 1.1).

$$
\mathrm{O}_{\mathrm{it}}-\mathrm{O}_{\mathrm{it}}{ }^{*}=\mathrm{f}^{*}\left(\mathrm{~F}_{\mathrm{i}}^{\left(\mathrm{t}-\mathrm{t}^{*}\right)}, \mathrm{P}_{\mathrm{i}}{ }^{\left(\mathrm{t}-\mathrm{t}^{*}\right)}, \mathrm{S}_{\mathrm{i}}{ }^{\left(\mathrm{t}-\mathrm{t}^{*}\right)}\right)+\mathrm{v}_{\mathrm{it}}-\mathrm{v}_{\mathrm{it}}{ }^{*}
$$

where:

$\mathrm{O}_{\text {it }}=$ performance of student $\mathrm{i}$ at time $\mathrm{t}$

$\mathrm{F}_{\mathrm{i}}=$ cumulative family inputs

$\mathrm{P}_{\mathrm{i}}=$ cumulative peer inputs

$S_{i}=$ cumulative school inputs

$\mathrm{v}_{\mathrm{it}}=$ stochastic term

and outcome changes over the period ( $\left.\mathrm{t}-\mathrm{t}^{*}\right)$ are related to inputs over the same time period 
This analysis allows for achievement growth to be a function of not only school inputs but also family, peer, and innate ability. More recent literature has added personal characteristics, such as gender and health in the form of obesity levels to the education production function.

A majority of the literature on the topic of student achievement has examined factors that affect only one grade level or one subsector or focused on only one factor influencing achievement. The goal of this dissertation is to expand the literature using the educational production function by looking at multiple grade levels as well as multiple factors that can be found to affect achievement. Chapter 2 will explore the effects of changing the school funding system to a more uniform system on achievement of students in elementary, middle and high school levels. This analysis differs from a majority of the previous literature by indicating that achievement in all fours grades in school districts with low levels of resources prior to reform were affected positively by increased funds. Chapter 3 also explores the relationship between school resources and achievement but this analysis looks at the funding source. In particular, excess school property tax levies, which bring in funds above and beyond the funding levels established through traditional means. This analysis also explores achievement at the elementary, middle and high school level and shows that additional classroom funds from excess levies that go to school districts that typically do not receive these additional funds has a positive impact on achievement in all four grade levels. Chapter 4 examines the effects of gender on the performance of students at the elementary school level. Other inputs such as family income levels, peer inputs, and school resources will be part of the panel model. The next three sections of this chapter will summarize the analysis done in Chapters 2, 3, and 4. 


\subsection{Effect of School Resources on Different Grade Levels}

The push for more funds for public education has been a common theme among parents, teachers, boards of educations, and legislatures. More funds are thought to increase the resources available to students and in turn increase the performance of each student in that particular area. In 1990, the West Virginia school system funding source, i.e. the property tax system, was significantly adjusted to promote the equalization of public education resources among the fiftyfive school districts in the state. This equalization of resources was established in order to develop high quality levels of education balanced across the state. This massive change was due to a court decision declaring the West Virginia public education funding system to be inadequate due to the wide variation in funding for public schools from school district (i.e. county) to school district. This variation in funding per pupil in the public education system was deemed to have deprived children in poorer or inadequately assessed school districts of their state constitutional right to a "thorough and efficient" free public education. Thus, in 1990, the property tax system was uniformed to assess property at 60 percent of fair market value. The revenues collected from the property tax for public education would be collected at the state level and then allocated to school districts in a uniform manner. Funding for variable expenditures (i.e. teacher salaries, transportation, etc.) were based on student enrollment levels while fixed expenditure funding was allocated by percentage-of-total support. The goal of the equalization of funding for public education in West Virginia was to equalize student performance across the state. Funding each pupil would be based on the same criteria and, in turn, should produce the same results in performance.

The positive relationship between school resources and student achievement expected in West Virginia after the passage of legislation in 1990 has been proved by many early researchers 
to be unlikely. The earliest research on the relationship between resources and achievement was the Coleman report in 1966 which concluded that school characteristics, including financing, were relatively unimportant to student performance levels. A multitude of research on the relationship between school resources and achievement using regression analysis while controlling for non-school inputs followed the Coleman report with the consensus backing up the conclusions of the report. Factors other than school resources, such as family and peer characteristics were demonstrated to have the primary influence over achievement.

Analysis into the effect of public education reform on the equalization of spending and the effect of that spending on student performance has also not resulted in a positive relationship between spending and achievement. Results indicate that the equalization of spending does not result in significant changes to overall student achievement except for the achievement levels of students from different backgrounds such as low income households. More recent analysis, however, found positive funding effects, especially at the elementary grade levels.

The goal of this analysis of the student achievement in West Virginia after the reform in 1990 was to examine over time how the convergence of spending across school districts affected student performance at different grade levels. Consistent with previous literature, production function analysis in conjunction with time and school district fixed effects was used on West Virginia school expenditure and achievement data from 1989 to 2002. Student achievement data, defined by standardized test results, as well as school, peer, family and school district inputs was analyzed for four grade levels: 3, 6, 9, and 11.The dataset for all grade levels was also broken down into two categories: low pre-policy spending and average or above average pre-policy spending. 
After the 1990 reform, uniform property tax appraisals coupled with revenue restricting legislation allowed property tax revenues in the state to rise which, in turn, led to an increase in the revenue base for funding public education. The increased funding for education had fundamentally different effects on different school districts and grade levels. School districts characterized as having average or above average levels of school resources per pupil prior to 1990 reform were found to not be significantly affected by the increase in revenues, which was consistent with previous literature. School districts in West Virginia from 1989 to 2002 with below average initial expenditures level, however, were affected quite differently. For these school districts, increased education expenditures per pupil had a positive and statistically significant influence on student achievement in all four grade levels. While these effects were calculated to be rather small there was clear evidence for their existence. The positive relationship between school resources and student performance was also supported in the analysis of all 55 school districts in the state during this same time period. Increases in public education expenditures per student from one year to the next were shown to have a positive and significant effect on the growth of student achievement for grades 6 and 9.

The results of this analysis of West Virginia suggest that there are important differences in the effects of spending on student achievement by sub-group. School districts that begin with low levels of school resources per pupil see an increase in the level of student achievement greater than those districts with average or above average resource or spending levels. Also, school resources are found to have different effects on different grade levels. Additional research is needed to establish if there is a threshold point above which additional spending does not produce significantly higher test scores. 


\subsection{Effect of Specific School Resources}

The assumed importance of increasing resources for public education has led to special property tax levies implemented by some school districts to raise funds above and beyond regular revenues received by traditional means. Approval for these additional or excess levies come from tax payers that are assured by tax levying bodies and educators that additional funds are needed to maintain or increase the educational standards of the school districts. Funds collected from the excess levies are distributed according to mandate voted on by the public. Typically school excess levy funds are used to supplement teacher salaries, buy new technology or classroom supplies, or provide free textbooks to students.

The assumption that additional school resources lead to higher levels of student performance has been long debated. In fact, since the groundbreaking research by Coleman in 1966, the relationship between student achievement and school resources have been widely analyzed with many concluding that family and peer inputs are more influential than school resources. More recent research, including Archibald (2006), find that school expenditures per pupil must be disaggregated into more meaningful categories in order to show the true effects of school resources on student performance.

This chapter explores how additional local school resources devoted to classroom supplies and teacher wage increases affects student achievement in West Virginia. Analysis of this state will delve into whether school districts without additional local revenues have lower performance than areas that consistently have excess levies and how these additional instructional funds affect performance in school districts that adopt an excess levy after not having one in place for many years. First, is a look at the characteristics that influence the adoption of a public education excess levy in West Virginia from 1992 to 2002. Results show 
that increases in the level of urbanization, measured by the number of students per square mile, increases the probability of adopting an excess levy at the school district level. This analysis also found that the probability that an excess levy for public education will be voted for declines as the percentage of the population in retirement age increases.

This dataset occurs just after the adoption of the 1990 Appraisal Act and the implementation of the Public School Support Program (PSSP) which uniformed the base for public education revenue and equalized the funding to all West Virginia school districts. Prior to, during, and after this equalization transformation, school districts were given the right to pass excess levies for public education. Analysis of the 55 school districts during this time shows that 39 to 43 school districts had a public education excess levy in place thus the 1990 Appraisal Act did not change the trend of excess levy adoptions.

Regression analysis at the school district level of school districts that consistently had an excess levy during this time period found that while the students in these school districts tended to score the highest on standardized tests the effect of these additional classroom revenues was not significant. However, for those school districts that were not reliant on additional funds from excess levies due to their constituencies not consistently adopting excess levies, effects on achievement from these additional funds was found. From 1992 to 2002, student performance in all four grade levels $(3,6,9$, and 11$)$ were positively effect in a significant manner by additional funds from the adoption of an excess levy. These results could help influence voters to adopt an excess levy to increase the educational attainment in their school district especially in those districts that tend to not vote in favor of them. Other factors, including peers, past academic performance, density rates, and poverty levels were also shown to significantly influence overall achievement. 


\subsection{Effect of Gender}

Numerous studies have examined the relationship between gender and academic achievement. Globally gender gaps have been found in student performance in mathematics (Marks, 2008; Else-Quest et. al., 2010; Schmidt and Kifer, 1989). Results show that boys in several countries tend to score higher in mathematics than girls of the same age. The same results have been found in the United States. Fryer and Levitt (2010) found that in a large nationally representative panel of children in the United States that a difference in mathematics was not present between boys and girls upon entry into school but within the first six years of school girls loose more than twotenths of a standard deviation compared to boys.

In West Virginia, however, from 2003 to 2007, the opposite result has been found for fifth graders. The percentage proficient on the state-wide standardized test of girls was significantly higher than the percent proficient in boys in mathematics. In order to quantify the effect gender had on this outcome, analysis of a dataset of school district level student achievement data of $5^{\text {th }}$ graders from 2003 to 2007 along with school, peer, family, and student inputs was examined.

Regression analysis shows that while girls had higher levels of proficiency in mathematics on standardized tests, the percentage of net enrollment that were girls did not significantly impact achievement in the subject. This result is consistent with the demographic analysis of $5^{\text {th }}$ graders in each school district. During this time period, the percentage of girls enrolled in the $5^{\text {th }}$ grade was not significantly different from the percentage of boys.

The next step in this analysis was to determine whether different inputs impacted mathematical achievement in boys differently than in girls. Results show that both genders are significantly influenced by higher achieving peers. Boys' mathematical performance was shown 
to be negatively impact by low performing peers, measured by the percent of students held back or retained. Girls' achievement was not shown to be affected by peers in a negative manner but rather by classroom size. As the level of students per teacher increases, the level of mathematical proficiency in girls in the $5^{\text {th }}$ grade declines, which indicates that girls perform better when there is more individual attention from teachers. 


\section{Chapter 2: Effect of School Resources on Different Grade Levels}

\subsection{Introduction}

During each legislative session, board of education meeting, and parent organization meeting there tends to be a push for more funds for public education. This initiative comes from the theory that additional school resources lead to higher student achievement. In West Virginia, this ideal has led policymakers to reform the funding system and source for K-12 education, i.e. the property tax system. The goal of this legislative change was to promote equalized public education resources among the fifty-five school districts in order to develop high quality levels of education across the state while equalizing student achievement across the state.

These legislative changes were spurred by court decisions declaring the public education funding system inadequate. This was due to the wide variation in funding for public schools from school district to school district, which was deemed to have deprived children in poorer or inadequately assessed counties of their state constitutional right to a "thorough and efficient" free public education. Thus, the property tax assessment system was uniformed to 60 percent of fairmarket value for all types of property. Uniform practices enabled the public school support system in the state to allocate property tax revenue in a manner deemed more equitable. Funding for variable expenses, such as teacher salaries and transportation, was based on student enrollment and percentage-of-total support for fixed expenses. It was assumed that equalization of the public education funding system would equalize student performance across the state as each school would receive funding based on the same criteria, which should in turn produce the same results.

However, early research on the relationship between school resources and student performance suggests that this outcome may be unlikely. Early economic research on this 
relationship has generally found no significant relationship between funding and student performance. Factors other than school resources, such as family and peer characteristics, have been demonstrated to influence student performance. Analysis of public education reform has shown that the equalization of spending does not result in significant changes to overall student achievement but did have an effect on achievement of students from different backgrounds such as low income households. More recent analysis, however, has found positive funding effects, especially at the elementary grade levels.

The goal of this paper is to examine over time how the convergence of spending across West Virginia school districts financed through an expanded public school revenue base affected student performance at different grade levels. The results indicate a positive and significant relationship between school resources and student performance in students that attended class in school districts with below average expenditures per student prior to the funding change. The rise in school expenditures per pupil in these low pre-policy spending districts had a statistically significant influence on the growth of student achievement. In areas of the state where expenditures per student were above the state average prior to the policy change, student performance in all grade levels was not shown to be significantly affected by school resources but rather by family, school district, and peer characteristics.

The next section of the paper reviews the existing literature on the effect of school resources and school finance reforms on student achievement. Section 3 will explore the changes in school district expenditures in West Virginia with special emphasis on the transformation of public education expenditures after legislative changes to the property tax system were implemented. The final section of the paper includes analysis of a panel of school district-level ${ }^{1}$

\footnotetext{
${ }^{1}$ West Virginia school districts correspond with counties.
} 
student achievement scores from 1989 to 2002. The data is used to assess whether the convergence in spending levels per student had important effects on student achievement.

\subsection{Previous Literature}

The effect of school resources on student performance and the effect of school finance equalization reforms on student achievement have been major topics in the economics and education literature. Research assessing the connection between school resources and student achievement began with the Coleman report in 1966. This report, which was created on the heels of the Civil Rights Act of 1964, was mandated to explore the inequity in the provision of education. Coleman found that raising the level of school resources, which includes the lowering of class sizes, has no effect on student test scores. This study concluded that school characteristics, including financing, are relatively unimportant to student performance levels while families and peers are key elements to student success.

Coleman's analysis lead to a multitude of research using regression analysis to estimate the relationship between school resources and student performance while controlling for nonschool inputs such as family and peer characteristics. After three decades of research on the topic, Hanushek (1996) found that all empirical research backed up the conclusions of the Coleman report. The research showed that resources that are devoted to schooling are not the primary factor in determining student performance. Hanushek went on to discuss some central implications for policies related to school spending as it pertains to this conclusion. When examining resources that are prime determinants of variations in per pupil spending, i.e. teacherpupil ratio, teacher education, and teacher experience, Hanushek found that these resources were split with teacher experience having the most positive and statistically significant relationship 
with student achievement but all three factors sometimes had negative and significant impacts. When combining these results with the steady and large expansion of resources devoted to schools, Hanushek not surprisingly, found that aggregate spending trends have nothing to do with aggregate student achievement. Hanushek concluded that while it may be necessary to increase spending on schools, restructuring of current resources in accordance with making teachers and schools better must be first accomplished.

Hanushek expanded research on this topic in 2006 by investigating how school resources and other factors relate to student performance through an education production function analysis. This production function allows the performance of a student at a particular time to be a function of family inputs, peer inputs, school inputs, innate ability, and a stochastic term. Due to the cumulative nature of student achievement, Hanushek examined a modified production function that takes into account the time path of inputs. This value added formulation analyzed the growth in contemporaneous performance over a time period as shown in Equation 2.1.

$$
\mathrm{O}_{\mathrm{it}}-\mathrm{O}_{\mathrm{it}} \mathrm{t}^{*}=\mathrm{f}^{*}\left(\mathrm{~F}_{\mathrm{i}}{ }^{\left(\mathrm{t}-\mathrm{t}^{*}\right)}, \mathrm{P}_{\mathrm{i}}{ }^{\left(\mathrm{t}-\mathrm{t}^{*}\right)}, \mathrm{S}_{\mathrm{i}}{ }^{\left(\mathrm{t} \mathrm{t}^{*}\right)}\right)+\mathrm{v}_{\mathrm{it}}-\mathrm{v}_{\mathrm{it}}{ }^{*}
$$

where:

$\mathrm{O}_{\mathrm{it}}=$ performance of student $\mathrm{i}$ at time $\mathrm{t}$

$F_{i}=$ cumulative family inputs

$\mathrm{P}_{\mathrm{i}}=$ cumulative peer inputs

$\mathrm{S}_{\mathrm{i}}=$ cumulative school inputs

$\mathrm{v}_{\mathrm{it}}=$ stochastic term

and outcome changes over the period (t-t*) are related to inputs over the same period

Hanushek examined 376 production function estimates that were published in 89 articles prior to 1995 which included a variation of the previously mentioned production functions, used school and family inputs, and provided the sign and significance of the resource relationship with a measurable school outcome. Of these production function estimates, Hanushek concluded that, after examining teacher-pupil ratios, teacher education, and teacher experience, adding more of 
these resources may not boost student achievement. The estimates also showed weak support for the idea that providing higher teacher salaries or higher levels of overall spending will lead to improved student performance.

An examination of the effects of school spending on different grade levels resulted in the same results: increasing public education funding does not necessarily raise the level of student performance (Sharp 1993). This analysis was completed in Illinois in 1993 during an era of major court decisions regarding the restructuring of school finance systems in many states. The results suggested that additional public education funding should be targeted to specific programs instead of a general increase in order to effectively increase student performance.

More recent studies of student finance reform have delved into the effect of reform on the equalization of spending and the effect of that spending on student performance, with mixed results. Murray, Evans, and Schwab (1998) investigated school finance reform in 16 states and found that court-ordered finance reform reduced within-state inequity in spending by 19 to 34 percent. Downes and Figlio (1997) also looked at court mandated school finance reforms that occurred during the 1980's and found that these reforms did not result in significant changes in either the mean level of the distribution of student performance on standardized tests of reading and mathematics for high school seniors. Downes and Figlio (1997) also examined substantial education finance reforms that were not responses to court mandates and found increases in mean student performance. An examination of the effect of school finance reform on the distribution of school spending across rich and poor school districts and the consequences of spending equalization of student achievement was completed by Card and Payne in 2002. Their analysis looked at SAT score distributions before and after spending gaps between richer and poorer districts were narrowed through school finance reform in the 1980s. Card and Payne 
found evidence that equalization of spending actually lead to a narrowing of test score outcomes across family background groups. Their analysis included the examination of school aid formulas found in each state, school district expenditures, and SAT scores from 1978-1992, and concluded that spending equalizations that followed unconstitutional court rulings in twelve states closed the gap in average SAT scores between children with highly-educated and poorlyeducated parents by approximately five percent.

Changes to public education financing and its effect on student achievement have also been examined at the state level. Papke $(2005,2008)$ looked at the effects of Proposal A that was passed in Michigan in 1994. Papke found that the increased spending had positive and significant effects on math pass rates for fourth graders, especially in initially poor performance school districts. Vermont's Act 60 was found to have the same impact on fourth grade pass rates as in Michigan (Sherlock, 2011).

More in-line with recent research, data from a large randomized study in Tennessee seems to provide convincing evidence that school resources do have a positive effect on student performance. The Tennessee STAR experiment randomly assigned kindergartners to small and large classes and followed their progress over four years. Results indicate that smaller class sizes, a major source of increased cost in education production functions, lead to higher test scores (Finn and Achilles 1990). These results remain after econometric analysis is used to correct for problems of experiment design and implementation (Kruger 1999). The kindergarten test scores were also found to be highly correlated with adult outcomes. Chetty et. al. (2011) found through linking the STAR data to federal tax forms that the kindergarten students that were randomly assigned into high quality classrooms had higher earnings at age 27 and were more likely to have attended college. Chetty et. al. concluded that the impacts of class quality on 
student achievement diminished in later grades but the gains in non-cognitive measures continued.

\subsection{Public Education Expenditures}

West Virginia public education support system's funding base, as determined by state code, was altered after constitutional changes to property tax law in the early 1990's. These changes, deemed the Appraisal Act of 1990, increased the level of property subject to the property tax by requiring that all school districts ${ }^{2}$ assess property uniformly in three-year cycles at sixty percent of fair market value. Many of the school districts prior to this legislation assessed at levels well below sixty percent. Thus, this legislation was expected to make the property tax system uniform across counties as well as increase the amount of property taxes levied in the state. This broadening of the base for the state's public education support system provided the extra funds needed to make spending per student more equitable across school districts. ${ }^{3}$

The West Virginia Public School Support Program (PSSP) was established in line with the passage of the Appraisal Act of 1990. The PSSP is a plan of financial support for the public schools in the state which uses a seven step formula to allocate property tax revenue to all 55 school districts. Ninety-eight percent of revenues collected at the school district level for public education through property taxes each year were sent to the state to be used in the PSSP. The PSSP was a basic foundation allowance program that provided funding to local school districts for personnel salaries, employee benefit costs, transportation operating costs, general operating costs, substitute costs, allowances for faculty senates, and improvement of instructional

\footnotetext{
${ }^{2}$ West Virginia school districts are constructed at the county level. Thus, all data used in this analysis is for the county.

${ }^{3}$ One source of funds above and beyond the funding from the PSSP comes from excess levies passed at the school district level. Public education excess levies are additional property taxes imposed on residents after a vote by these residents. The additional funding goes to classroom supplies, teacher pay, and benefits.
} 
programs. Allowances for personnel were based on net enrollment for each school district while utility and improvement cost allowances were determined as a percentage of total costs incurred in the school district.

The requirement that all property be assessed at 60 percent of fair market value increased the revenue base for public education in West Virginia (Figure 2.1). In 1990, total revenue for public education in the state totaled approximately $\$ 1.3$ billion. By 1992, public education revenue increased by $\$ 280$ million nominally. In real terms, public education revenue had increased to $\$ 1.48$ billion by 1992 . Total public education revenue continued to rise after 1992 and by 1996 the total public education revenue base surpassed $\$ 2$ billion.

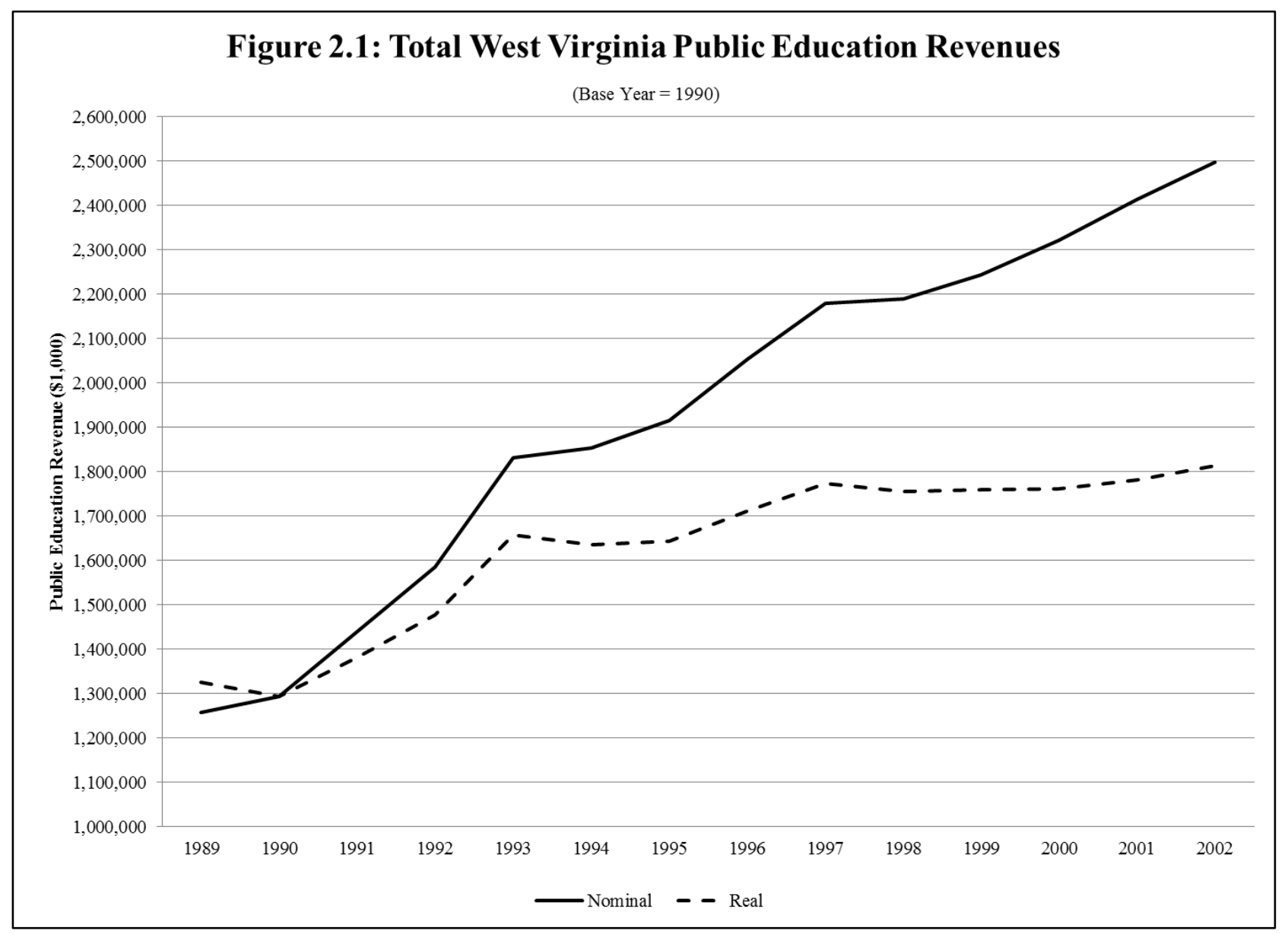


In the five years ${ }^{4}$ prior to the passage of the Appraisal Act, public education spending per pupil averaged $\$ 4,329$ in real terms ${ }^{5}$. The standard deviation of expenditures per pupil was 1,543 meaning 68 percent of expenditures fell in the range of $\$ 2,786$ per student to $\$ 5,872$ per student. The distribution of expenditures, however, narrowed in the next five years. From 1990 to 1994, public education expenditures per student averaged a level similar to the previous five years equaling $\$ 4,684$. Distribution of expenditures was more tapered with a standard deviation of 748 and thus 68 percent of school district expenditures ranged from $\$ 3,936$ to $\$ 5,432$.

The Appraisal Act of 1990 and the PSSP formula seemed to have accomplished their goals of equalizing funding across the state. In fact, analysis of expenditures per student surrounding the passage and implementation of the legislation indicates that average expenditures remained relatively constant in real terms while the distribution of expenditures across school districts began to converge. School districts with lower than average expenditures per pupil prior to 1990 increased spending while those areas with above average spending lowered their levels or remained constant. Figure 2.2 shows the distribution of West Virginia school districts that were affected in terms of real expenditures per student from prior to the legislative changes in 1990 to four years after the changes were implemented. From 1989 to 1994, real expenditures per student declined in seven school districts in West Virginia. Declines in revenue per student varied in these seven school districts from 3 to 22 percent while the counties that had a positive increase in revenues per student experienced increases of 0.5 to 84.1 percent. With converging of expenditures across the state, the next step is to investigate the effect on the student achievement in all school districts with special emphasis on school districts that experienced the most change in expenditures per pupil.

\footnotetext{
${ }^{4}$ Public education expenditure data prior to 1985 was not available for all school districts within West Virginia. ${ }^{5}$ Expenditures per student were calculated holding student enrollment constant at the 1990 level. Base year for establishing real expenditures per student was 1990.
} 


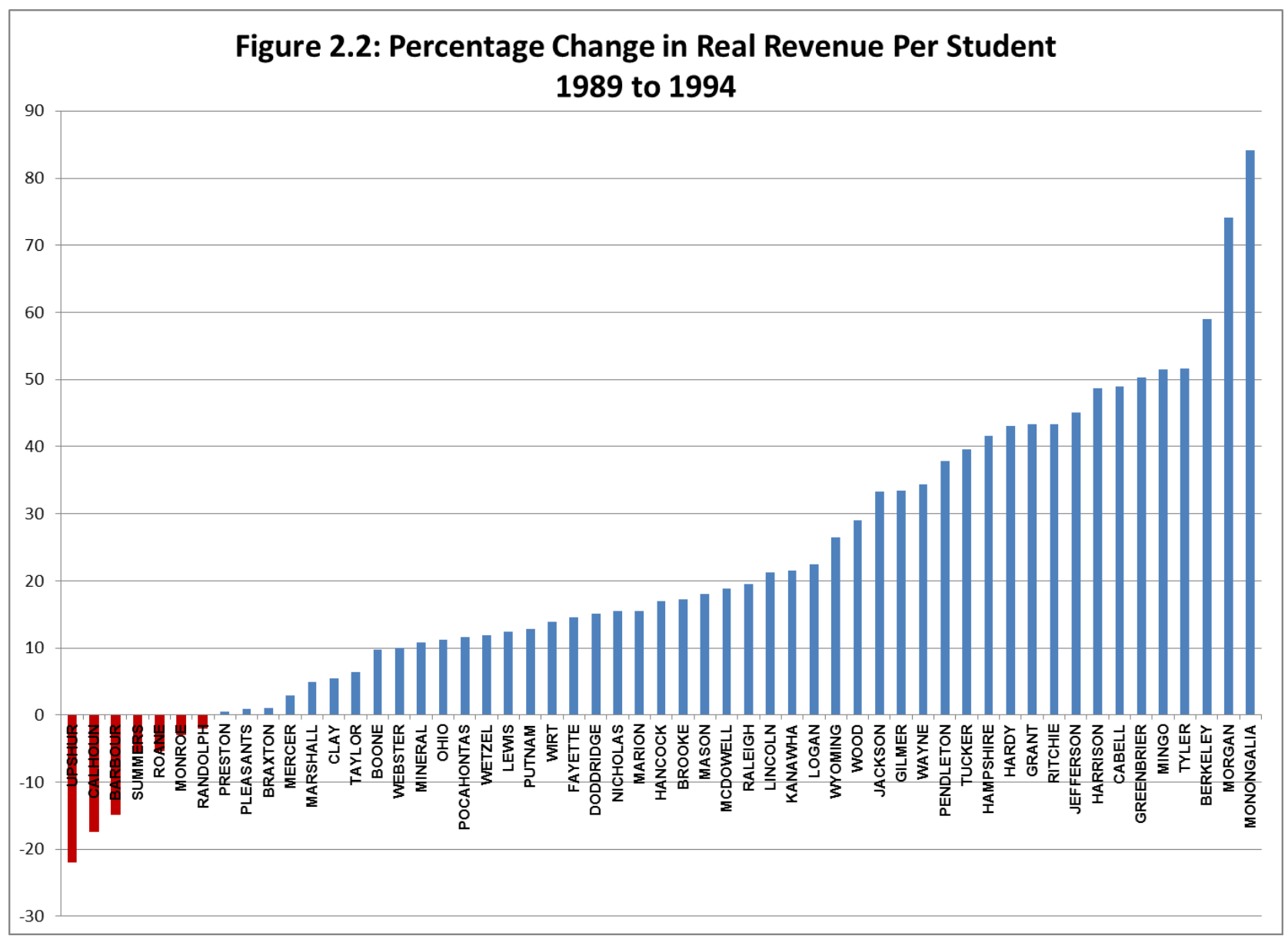

\subsection{Effect on Student Achievement}

\section{A. Methodology}

Consistent with the previous literature, production function analysis in conjunction with time and school district fixed effects was used to determine if school expenditures affect student performance in West Virginia from 1989 to 2002. Student achievement for four grade levels, as well as school, peer, family, and school district inputs were factored into the OLS regression analysis. Dummy variables were included for each year of the data set as well as for each of the 55 school districts within the state. Student mean percentile scores were the dependent variables in this fixed effects model, as shown in Equation 2.2. 
The dataset was broken down into two categories: low pre-policy spending and average or above average pre-policy spending. ${ }^{6}$ Twenty-nine school districts, whose expenditures per student were below the state average prior to changes to the public education revenue source, made up the low spending group. Expectations are that if increased school resources have an effect on performance then the areas that began with low expenditures per pupil would be affected the most. The higher spending group consists of the remaining school districts and will service as a basis for effect of average or above average expenditures on student performance.

\section{B. Data}

West Virginia data provides a unique opportunity to examine the effects of resources on student achievement as there has been a recent convergence in education spending across districts. Data for control variables is more readily available as West Virginia school districts are established at the county level. Further, this analysis of West Virginia student achievement examines the effect school resources have on four different grade levels over an extended time period.

Aforementioned, previous research on student achievement and the effects of public education resources concentrated on only one grade level or if multiple grades were analyzed only a few years of data were analyzed.

Previous literature that analyzed the effect of resources on student achievement used two basic forms of data to measure student performance: SAT scores and standardized test scores. To see the effect on West Virginia students, mean standardized test scores for each school district

\footnotetext{
${ }^{6}$ Chow test results show that coefficients for these two groups are statistically different.
} 
were used. The data for this analysis was drawn from West Virginia school districts from 1989 to 2002 for four grade levels. Student achievement was measured by mean standardized test scores for total basic skills in grades three, six, nine, and eleven for all fifty-five school districts in the state. These scores are the result of a statewide student achievement testing program, which is mandated for public schools within the state. Table 2.2 shows the mean score for each grade level in West Virginia from 1989 to 2002 . Note that mean scores for West Virginia students were the highest in the lower grades during this time period. Distribution of student achievement scores suggests that in at least a few of the grades the goal of the West Virginia legislature had of equality in resource distribution and student performance was reached after the full implementation of the Appraisal Act and the PSSP formula in 1994. Student standardized score distribution in grades nine and eleven began to converge after 1995 with the distance between the minimum and maximum scores narrowing. While there seems to be some mean score convergence, the coefficients of variation prove the contrary (Table 2.1). The dispersion of mean scores has a propensity to actually broaden starting in 1996. Moreover, coefficients of variation for grades 6, 9, and 11 grow statistically after the full implementation of the Appraisal Act and subsequent rise in school revenue.

To analyze if there exists a significant relationship between additional school resources and student performance, real public education expenditures per student for each school district 
in West Virginia were collected. Expenditures were measured as the amount allocated to each county for K-12 public education through the state's PSSP. ${ }^{7}$ As previously mentioned, West Virginia's PSSP is the total basic foundation program for public education within the state. This program determines the distribution of funds to each school district by summing the computed costs for the following allowances: professional educators, service personnel, fixed charges, transportation costs, administrative costs, other current expenses, and allowances to improve instructional programs. The total amount allocated was then divided by the total net enrollment ${ }^{8}$ in each county for each school year. The implementation of expenditures at the classroom level, however, does not occur immediately. For instance, if public education expenditures increase, the effect of those additional monies at the classroom level in the form of new technology, additional teachers and so on will not impact the students in that school year. Those additional monies must flow through the school district then through the schools and finally to the classrooms. Due to these implementation delays, expenditures per student in this analysis were lagged two years. Expenditures per student are listed in real terms to account for inflation during this time span. As shown in Table 2.2, real expenditures per student did not vary by grade level.

Figure 2.3 explores the relationship between real expenditures per student and mean standardized test scores in West Virginia by displaying the distribution of $9^{\text {th }}$ grade $^{9}$ scores prior to and after the legislative changes by the school district's percentage change in real expenditures per student. Ninth grade scores from 1989 ranged between 36 and 76 for the 55 school districts while the scores from after the legislation ranged between 48 and 75, which indicate that

\footnotetext{
${ }^{7}$ From 1989 to 2002, revenues allocated to all 55 school districts accounted for, on average, over 75 percent of total revenues acquired for public education. The remaining revenue for each school district was acquired through federal grants and local public education excess levies and bonds.

${ }^{8}$ Net enrollment includes the number of pupils enrolled in special education programs, kindergarten programs, and grades one to twelve of the public schools in the county according to §18-9A-2 WV Code.

${ }^{9}$ Distribution is similar for grades 3, 6, and 11 .
} 
achievement levels were beginning to equalize among the 55 school districts. The data displayed in Figure 2.3 also reveals that the school districts that experienced the largest change in real expenditures per student did not have the maximum or minimum mean standardized test scores for 1989 or 1994. In fact, the school district that had the highest $9^{\text {th }}$ grade average standard test score in 1989 (Tyler County) also had the highest score in 1994 and increased real expenditures per student by 51.6 percent. The achievement level for the school district that had the largest increase in real expenditures per student only increased average achievement on the standardized test from 58 to 60 by 1994 while the average standardized test score for the school district with the largest decline in expenditures varied by only one percent. The small change in achievement in the school districts that experienced the largest change in real expenditures indicates that the change in school resources may not have had a significant impact on achievement. 


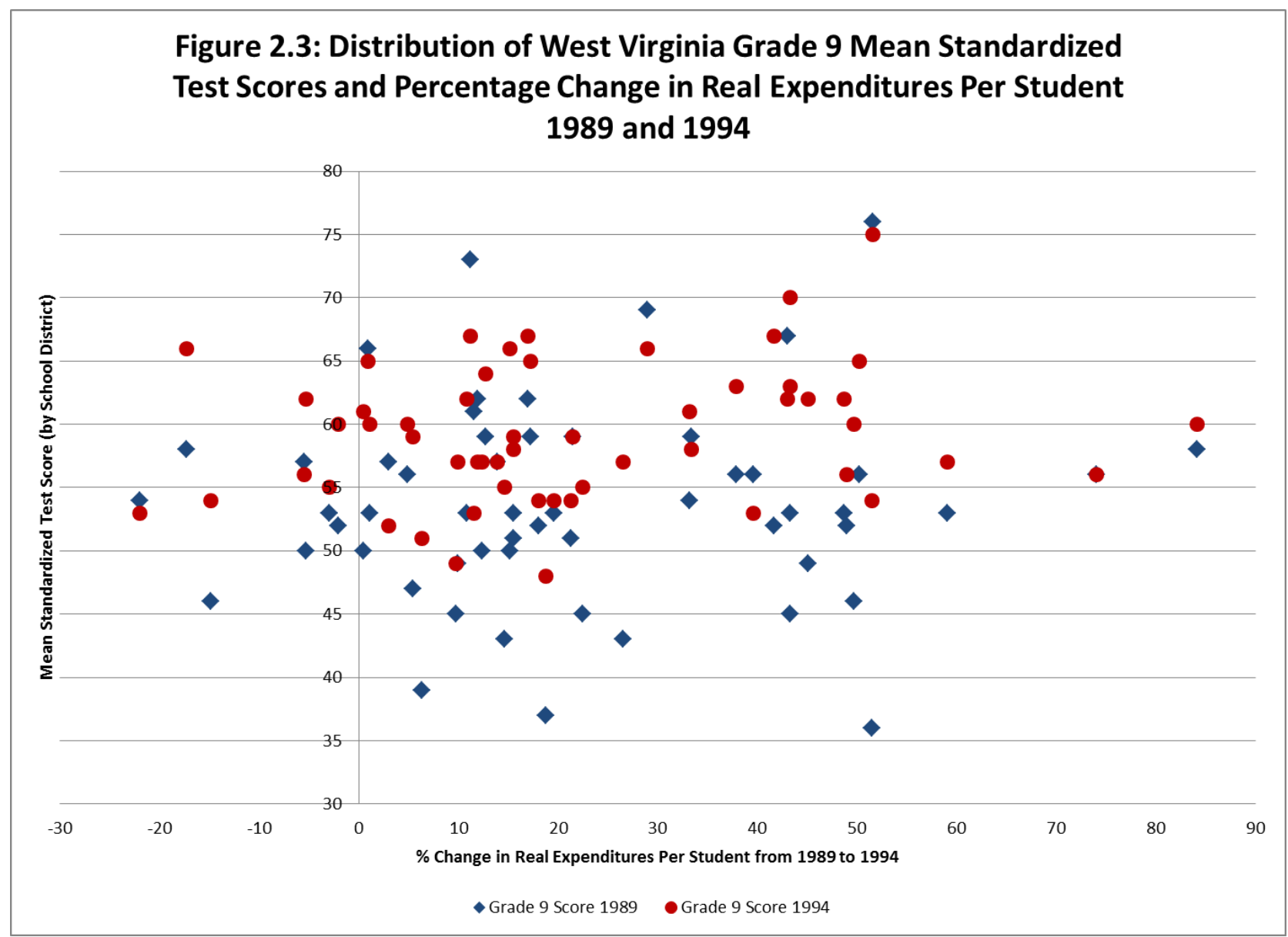

Previous literature has revealed that inputs outside of public education expenditures may have a positive effect on student performance. To account for these effects, school district level data from 1989 to 2002 on pupil-teacher ratios and average educational experience for teachers were collected. Pupil teacher ratios measure the average number of students for each full-time equivalent (FTE) teacher ${ }^{10}$. This ratio was derived by dividing public school net enrollment by the number of FTE teachers in each county for each school year. Some of the aforementioned literature found that pupil teacher ratios may have a positive and significant effect on student performance (Hanushek 1996). The average level of educational experience for teachers was derived by dividing the sum of all years of experience by the number of teachers employed and

\footnotetext{
${ }^{10}$ FTE teachers include head teachers, classroom teachers, JROTC instructors, and permanent substitutes.
} 
was used as a measure of teacher quality. Previous research, however, has demonstrated that higher levels of teacher experience may not lead to improved student achievement.

Peer inputs have been argued as having significant effects on student achievement.

Notably, empirical analysis on the effect of peer achievement indicates a positive and significant effect on student achievement growth (Hanushek et. al. 2003). This result follows the thought that students benefit more from high achieving schoolmates than average or low achieving peers. In order to capture the effect of peers in West Virginia from 1989-2002, retention rates were captured in the analysis. Retention rates, ${ }^{11}$ expressed as a percentage of enrolled students, are defined as the number of students held back a year or retained. These rates demonstrate the number of students for each grade level that did not meet qualifications to be promoted to the next grade level at the end of the school year.

Coleman (1966) found in analysis of student test scores that families are one of the key elements to student success. To capture the effect families have on student achievement, estimates of low income levels for families with school age children in West Virginia were included in the production function analysis. Variables considered as an estimate of family influence include the number of students eligible for free or reduced lunch and the number and percentage of five to seventeen years olds from families in poverty. To qualify for free or reduced price lunch, family characteristic qualifications for each child must be met. These qualifications, which include family size and income levels, are adjusted annually and all school children whose family meets these qualifications must be offered free or reduced price lunches by the school in which they are enrolled. Regression analysis results indicated that the percentage of school age children in impoverished families had the most explanatory power of

${ }^{11}$ Due to data availability, student retention rates were not available for grades 9 and 11 . Dropout rates for these grades were considered but after further examination were not used due to a change in how rates were calculated during the 1995-96 school year. 
the family inputs. From 1989 to 2002, the percentage of school-age children living in impoverished families was $25.9 \%$ (Table 2.2).

The type of environment in which students live may also have an effect on student achievement. To account for this affect, school district achievement, geographic, and demographic trends were included in the analysis. Past performance on standardized test for each grade indicates not only the expected achievement level for current students but may also indicate the quality of teachers and classroom resources typical for the school district. Past achievement levels will be measured for each grade by the mean standardized test scores in the school district from 2 years prior. Density rates, which can be used to show how rural each school district was for each school year, were calculated to be the number of students enrolled in grades $3,6,9$, and 11 per square mile of the county for which they were enrolled. Thus, grade 3 student density for each county would be equal to the number of students enrolled in grade 3 in that county for that school year per square mile of that county. For this time period, there was, on average, 1.12 third graders per square mile in West Virginia (Table 2.2). Population and per capita personal income levels were both examined, however, in final tabulations only per capita personal income of each county from 1989 to 2002 was found to have an effect on student achievement. Due to little variation in the race of the population of West Virginia from 1989 to 2002, race was excluded from the analysis. 


\begin{tabular}{|c|c|c|c|c|}
\hline \multicolumn{5}{|c|}{ Table 2.2: } \\
\hline \multicolumn{5}{|c|}{ Determinants of Student Achievement in West Virginia: 1989-2002 } \\
\hline \multicolumn{5}{|c|}{ Summary Statistics } \\
\hline \multicolumn{5}{|c|}{ Full Dataset: Mean (Standard Dev.) } \\
\hline & Grade 3 & Grade 6 & Grade 9 & Grade 11 \\
\hline Mean Standardized test score & 64.34 & 61.23 & 56.95 & 57.99 \\
\hline (Dependent Variable) & $(6.69)$ & $(6.79)$ & $(6.41)$ & $(6.42)$ \\
\hline \multirow[t]{2}{*}{ Real school expenditures per student ${ }^{1}(\$ 1,000)$} & $5,863.40$ & $5,863.40$ & $5,863.40$ & $5,863.40$ \\
\hline & $(2,720.10)$ & $(2,720.10)$ & $(2,720.10)$ & $(2,720.10)$ \\
\hline \multirow[t]{2}{*}{$\%$ Retained } & $1.74 \%$ & $2.09 \%$ & - & - \\
\hline & $(2.19)$ & $(5.80)$ & - & - \\
\hline \multirow[t]{2}{*}{ Pupil-teacher ratio } & 14.59 & 14.59 & 14.59 & 14.59 \\
\hline & $(0.96)$ & $(0.96)$ & $(0.96)$ & $(0.96)$ \\
\hline \multirow[t]{2}{*}{ Average Teacher Experience } & 16.21 & 16.21 & 16.21 & 16.21 \\
\hline & $(2.40)$ & $(2.40)$ & $(2.40)$ & $(2.40)$ \\
\hline \multirow[t]{2}{*}{$\%$ Poverity } & $25.88 \%$ & $25.88 \%$ & $25.88 \%$ & $25.88 \%$ \\
\hline & $(8.42)$ & $(8.42)$ & $(8.42)$ & $(8.42)$ \\
\hline \multirow[t]{2}{*}{ Past School District Performance (2 yr lagged) } & 64.67 & 61.37 & 56.47 & 57.57 \\
\hline & (7.02) & (6.99) & $(6.96)$ & $(6.70)$ \\
\hline \multirow[t]{2}{*}{ Student density (students per sq. mile) } & 1.12 & 1.16 & 1.22 & 1.05 \\
\hline & $(1.03)$ & $(1.06)$ & $(1.12)$ & $(0.98)$ \\
\hline \multirow[t]{2}{*}{ Per Capita Personal Income $(\$ 1,000)$} & 16.63 & 16.63 & 16.63 & 16.63 \\
\hline & (3.99) & (3.99) & (3.99) & (3.99) \\
\hline Observations & 770 & 770 & 770 & 770 \\
\hline
\end{tabular}

\section{Results}

The impact of additional school resources on student achievement in West Virginia from 1989 to 2002 varied according to spending and grade level. Starting with time and school district fixed effect regression analysis of school districts with state average or above average expenditures per student prior to the legislative change in 1990, student achievement was not found to be significantly impacted by additional expenditures (Table 2.3). Peer, family, and school district characteristics, however, were shown to significantly shape student performance. Standardized test scores of schoolmates from 2 years prior had positive and strongly significant effects on student achievement in all four grades. The average number of years of teacher experience had a negative impact in sixth and eleventh grade levels. Family inputs, such as percentage of school age children in families in poverty, were shown to have a significant influence on the high school level students. As the percentage of students in impoverished families increased, the level of 
student performance on standardized test scores significantly declined in ninth and eleventh grades. Another school district characteristic, urbanization, was shown to play a significant role in student performance. The level of students per square mile, or student density, was found to have a negative and significant influence all grade levels. Thus, the more students per square mile or more urbanized a school district was the lower the level of student performance. This result is consistent with the distribution of $9^{\text {th }}$ grade mean standardized test scores displayed in Figure 2.3, where the lowest scoring school district in both 1989 and 1994 had one of the top student density rates in the state.

Table 2.3:

Determinants of Student Achievement in West Virginia: 1989-2002 Time and School District Fixed-Effects Model Average or Above Average Pre-Policy Spending Group (Dependant Variable: Grade-Level Mean Standarized Score)

\begin{tabular}{|c|c|c|c|c|}
\hline & Grade 3 & Grade 6 & Grade 9 & Grade 11 \\
\hline \multirow[t]{2}{*}{ Real School expenditures per student $(\$ 1,000)$} & 0.0169 & 0.0083 & 0.0034 & 0.0052 \\
\hline & $(0.01)$ & $(0.01)$ & $(0.01)$ & 0.01 \\
\hline \multirow[t]{2}{*}{$\%$ Retained } & -3.3904 & -2.9650 & - & - \\
\hline & $(7.57)$ & $(2.65)$ & & \\
\hline \multirow[t]{2}{*}{ Pupil-teacher ratio } & -0.4002 & $-0.7800^{*}$ & -0.6089 & -0.2365 \\
\hline & $(0.63)$ & $(0.43)$ & $(0.64)$ & $(0.56)$ \\
\hline \multirow[t]{2}{*}{ Average Teacher Experience } & -0.5475 & $-1.0280^{* *}$ & -0.3552 & $-1.1266^{* *}$ \\
\hline & $(0.37)$ & $(0.41)$ & $(0.42)$ & $(0.44)$ \\
\hline \multirow[t]{2}{*}{ \% Poverity } & -0.1075 & -0.0324 & $-0.3642^{* * *}$ & $-0.2924^{\star *}$ \\
\hline & $(0.13)$ & $(0.12)$ & $(0.12)$ & $(0.14)$ \\
\hline \multirow[t]{2}{*}{ Past school district performance (lagged 2 years) } & $0.1355^{\star *}$ & $0.5739^{* * *}$ & $0.2558^{\star * *}$ & $0.6432^{* * *}$ \\
\hline & $(0.07)$ & $(0.15)$ & $(0.06)$ & $(0.07)$ \\
\hline \multirow[t]{2}{*}{ Student density } & $-2.5575^{\star \star *}$ & $-4.0339^{* *}$ & $-2.2410^{* * *}$ & $-2.8562^{* * *}$ \\
\hline & $(0.47)$ & $(1.59)$ & $(0.31)$ & $(0.86)$ \\
\hline \multirow[t]{2}{*}{ Per Capita Personal Income } & -0.2561 & -0.2103 & -0.0462 & -0.3570 \\
\hline & $(0.35)$ & $(0.35)$ & $(0.42)$ & $(0.52)$ \\
\hline \multirow[t]{2}{*}{ Const. } & $66.1480^{* \star *}$ & $71.1086^{\star * *}$ & $52.3678^{\star \star *}$ & $79.2442^{\star \star \star}$ \\
\hline & $(12.47)$ & $(10.32)$ & $(11.04)$ & $(13.52)$ \\
\hline R squared & 0.63 & 0.60 & 0.64 & 0.54 \\
\hline Observations & 364 & 364 & 364 & 364 \\
\hline
\end{tabular}

Note: Percent of retained student for 9 th and 11 th grades were not available. Robust standard errors are shown in parentheses. Significance levels: ${ }^{\star \star \star}$ at $1 \%$, ${ }^{\star \star}$ at $5 \%$, and * at $10 \%$.

Regression results were considerably different for the school districts with low or below average pre-policy expenditures per student. Unlike the higher spending group, school resources added significant explanatory power to the analysis (Table 2.4). Real expenditures per student for all grades were positive and significant. However, for every $\$ 1,000$ increase in real public 
education spending per pupil, mean percentile scores increased the most in third grade and the least in ninth and eleventh grades. Note that the average annual increase in real expenditures per student from 1989 to 2002 was less than $\$ 50$ with the maximum increase in any one school district for any one year was less than $\$ 1,000$. Low performing peers also had a significant impact on third grade achievement, while personal income per capita had a positive impact.

Regression analysis also showed that the number of students per square mile or student density had a negative and significant influence in grades 3 and 6.

Table 2.4:

Determinants of Student Achievement in West Virginia: 1989-2002 Time and School District Fixed-Effects Model Low Pre-Policy Spending Group (Dependant Variable: Grade-Level Mean Standarized Score)

\begin{tabular}{|c|c|c|c|c|}
\hline & Grade 3 & Grade 6 & Grade 9 & Grade 11 \\
\hline \multirow[t]{2}{*}{ Real School expenditures per student $(\$ 1,000)$} & $0.0216^{\star *}$ & $0.0234^{\star *}$ & $0.02001^{* *}$ & $0.0199^{* *}$ \\
\hline & $(0.01)$ & $(0.01)$ & $(0.01)$ & $(0.01)$ \\
\hline \multirow[t]{2}{*}{$\%$ Retained } & $-29.9507^{*}$ & -0.2769 & - & - \\
\hline & $(15.32)$ & $(1.57)$ & & \\
\hline \multirow[t]{2}{*}{ Pupil-teacher ratio } & 0.4532 & 0.3261 & 0.3136 & 0.3307 \\
\hline & $(0.50)$ & $(0.49)$ & $(0.43)$ & $(0.47)$ \\
\hline \multirow[t]{2}{*}{ Average Teacher Experience } & 0.1781 & 0.1617 & $0.5390^{*}$ & 0.2410 \\
\hline & $(0.46)$ & $(0.41)$ & $(0.28)$ & 0.32 \\
\hline \multirow[t]{2}{*}{ \% Poverity } & 0.0324 & 0.0655 & -0.0294 & -0.1471 \\
\hline & $(0.13)$ & $(0.11)$ & $(0.10)$ & $(0.12)$ \\
\hline \multirow[t]{2}{*}{ Past school district performance (lagged 2 years) } & $0.1082^{*}$ & $0.1006^{\star *}$ & $0.1507^{\star *}$ & $0.2063^{\star * *}$ \\
\hline & $(0.06)$ & $(0.05)$ & $(0.06)$ & $(0.05)$ \\
\hline \multirow[t]{2}{*}{ Student density } & $-4.4144^{*}$ & $-4.1632^{\star *}$ & 0.0822 & 0.0244 \\
\hline & $(2.38)$ & $(1.69)$ & $(1.32)$ & $(0.77)$ \\
\hline \multirow[t]{2}{*}{ Per Capita Personal Income } & $0.3890^{\star *}$ & -0.1073 & -0.0168 & -0.1678 \\
\hline & $(0.16)$ & $(0.18)$ & $(0.21)$ & 0.24 \\
\hline \multirow[t]{2}{*}{ Const. } & $39.5703^{\star \star \star}$ & $39.3069^{\star * *}$ & $38.8904^{\star * *}$ & $39.9215^{\star \star *}$ \\
\hline & $(9.56)$ & $(10.52)$ & $(10.24)$ & $(11.24)$ \\
\hline R squared & 0.66 & 0.60 & 0.66 & 0.63 \\
\hline Observations & 406 & 406 & 406 & 406 \\
\hline
\end{tabular}

Note: Percent of retained student for 9 th and 11 th grades were not available. Robust standard errors are shown in parentheses. Significance levels: ${ }^{\star \star \star}$ at $1 \%$, ${ }^{\star \star}$ at $5 \%$, and ${ }^{*}$ at $10 \%$.

Comparing the above results to the existing literature is difficult, as most previous research does not divide the sample based on pre-policy spending. To be consistent with previous research, the model is re-estimated using the full dataset of 55 school districts, which combined the low spending and control groups, to see if the change in public education expenditures was influential on student performance across the state. Fixed effects regression 
analysis showed that school spending had a positive and significant effect on student achievement for two grade levels in the state (Table 2.5). For each $\$ 1,000$ increase in expenditures per pupil, mean percentile scores increased by 0.02 in sixth grade and ninth grade. These coefficients are small like those found in the low pre-policy spending group however the coefficient on spending is no longer significant for the third and eleventh grade providing suggestive evidence that the common finding of no impact of spending on student achievement in pooled samples might be masking the effects for subgroups. That is, there might be a threshold beyond which additional funding has little impact on student achievement but the effects might be significant for school districts below the threshold. As found in previous research, family and school district inputs had a significant impact on student performance. Standardized test scores from previous students had a positive effect for all four grade levels while student density levels continued to have a negative effect. The percentage of children residing in impoverished homes also had a negative and significant influence but for only grades nine and eleven. 


\begin{tabular}{|c|c|c|c|c|}
\hline \multicolumn{5}{|c|}{ Table 2.5: } \\
\hline \multirow{2}{*}{\multicolumn{5}{|c|}{$\begin{array}{c}\text { Determinants of Student Achievement in West Virginia: 1989-2002 } \\
\text { Time and School District Fixed-Effects Model }\end{array}$}} \\
\hline & & & & \\
\hline \multicolumn{5}{|c|}{ Full Dataset } \\
\hline \multicolumn{5}{|c|}{ (Dependant Variable: Grade-Level Mean Standarized Score) } \\
\hline & Grade 3 & Grade 6 & Grade 9 & Grade 11 \\
\hline \multirow[t]{2}{*}{ Real school expenditures per student $(\$ 1,000)$} & 0.0106 & $0.0164^{\star}$ & $0.0211^{\star *}$ & 0.0068 \\
\hline & $(0.01)$ & $(0.01)$ & $(0.01)$ & $(0.01)$ \\
\hline \multirow[t]{2}{*}{$\%$ Retained } & -2.6534 & -2.8701 & - & - \\
\hline & $(1.98)$ & $(2.19)$ & & \\
\hline \multirow[t]{2}{*}{ Pupil-teacher ratio } & -0.0461 & -0.0599 & $-0.5305^{\star}$ & -0.2978 \\
\hline & $(0.33)$ & $(0.33)$ & $(0.30)$ & $(0.33)$ \\
\hline \multirow[t]{2}{*}{ Average Teacher Experience } & -0.1232 & -0.2538 & 0.0655 & -0.2113 \\
\hline & $(0.20)$ & $(0.25)$ & $(0.25)$ & $(0.25)$ \\
\hline \multirow[t]{2}{*}{$\%$ Poverity } & -0.0602 & -0.0773 & $-0.1902^{* *}$ & $-0.2909^{* * *}$ \\
\hline & $(0.07)$ & $(0.07)$ & $(0.08)$ & $(0.09)$ \\
\hline \multirow[t]{2}{*}{ Past school district performance (lagged 2 yrs) } & $0.1157^{* * *}$ & $0.1122^{* * *}$ & $0.2096^{* * *}$ & $0.1449^{* * *}$ \\
\hline & $(0.04)$ & $(0.04)$ & $(0.04)$ & $(0.04)$ \\
\hline \multirow[t]{2}{*}{ Student density } & $-4.5773^{\star \star \star}$ & $-3.5248^{\star \star \star}$ & $-2.9754^{* \star *}$ & $-2.8245^{\star *}$ \\
\hline & $(1.30)$ & $(1.05)$ & $(0.70)$ & $(1.03)$ \\
\hline \multirow[t]{2}{*}{ Per Capita Personal Income } & 0.0985 & 0.0976 & 0.1009 & $0.2723^{\star *}$ \\
\hline & $(0.15)$ & $(0.15)$ & $(0.15)$ & $(0.12)$ \\
\hline \multirow[t]{2}{*}{ Const. } & $87.2676^{\star * *}$ & $82.5576^{* * *}$ & $68.0790^{* * *}$ & $74.2870^{* * *}$ \\
\hline & (9.39) & (8.59) & (7.99) & $(8.86)$ \\
\hline R squared & 0.68 & 0.62 & 0.65 & 0.60 \\
\hline Observations & 770 & 770 & 770 & 770 \\
\hline
\end{tabular}

To test the hypothesis that the relationship between real expenditures per student and mean standardized test scores was different in school districts with low pre-policy spending than in school districts with average or above average pre-policy spending, analysis of the combined effect of low spending and expenditures per pupil on student achievement was completed. A dummy variable indicating if a school district had below average expenditures prior to the policy change was included along with an interaction term to show if the effect of real expenditures per student was significantly modified by being a school district with below average expenditures prior to the 1990 policy change (Table 2.6). Regression results ${ }^{12}$ show a positive and significant joint effect of the interaction and being a low expenditure school district on achievement for three of the four grade levels. The effect was 159.2 in grade three, 50.1 in sixth grade, and 190.8

\footnotetext{
${ }^{12}$ By adding an interaction term to the analysis, the effect of real expenditures per student on mean standardized test scores is represented by everything that is multiplied by real expenditures per student in the model (i.e. the coefficient for real expenditures per student and the coefficient for the interaction term) and the effect of a low prepolicy school district is represented by its coefficient and the coefficient for the interaction term.
} 
in grade nine. The joint effect of the interaction and lagged expenditures per pupil was significant for student performance in grade nine. The impact for this grade for below average school districts was 0.02 and for all other school districts was -0.01 .

\begin{tabular}{|c|c|c|c|c|}
\hline \multicolumn{5}{|c|}{ Table 2.6: } \\
\hline \multicolumn{5}{|c|}{ Determinants of Student Achievement in West Virginia: 1989-2002 } \\
\hline \multicolumn{5}{|c|}{ Time and School District Fixed-Effects Model } \\
\hline \multicolumn{5}{|c|}{ Full Dataset } \\
\hline \multicolumn{5}{|c|}{ (Dependant Variable: Grade-Level Mean Standarized Score) } \\
\hline & Grade 3 & Grade 6 & Grade 9 & Grade 11 \\
\hline \multirow[t]{2}{*}{ Real school expenditures per student $(\$ 1,000)$} & -0.0113 & -0.0840 & -0.0091 & -0.0096 \\
\hline & $(0.01)$ & $(0.02)$ & $(0.02)$ & $(0.02)$ \\
\hline \multirow[t]{2}{*}{ Low Pre-policy Spending (Dummy Term) } & $16.0941^{* * *}$ & $13.7195^{\star * *}$ & $9.6546^{* \star *}$ & 5.1148 \\
\hline & $(4.49)$ & (3.98) & (3.27) & $(4.13)$ \\
\hline \multirow[t]{2}{*}{ Interaction Term (Exp. Per student * Dummy) } & $0.0244^{\star *}$ & -0.0062 & $0.0309^{* * *}$ & 0.0219 \\
\hline & $(0.01)$ & $(0.01)$ & $(0.01)$ & $(0.02)$ \\
\hline \multirow[t]{2}{*}{$\%$ Retained } & -3.1001 & -2.9108 & - & - \\
\hline & $(2.98)$ & $(2.19)$ & & \\
\hline \multirow[t]{2}{*}{ Pupil-teacher ratio } & 0.0084 & -0.0536 & -0.3124 & -0.2901 \\
\hline & $(0.33)$ & $(0.33)$ & $(0.30)$ & $(0.33)$ \\
\hline \multirow[t]{2}{*}{ Average Teacher Experience } & -0.0967 & -0.2610 & 0.1089 & -0.2556 \\
\hline & $(0.23)$ & $(0.22)$ & $(0.26)$ & $(0.29)$ \\
\hline \multirow[t]{2}{*}{ \% Poverity } & -0.0565 & -0.0781 & $-0.1879^{* *}$ & $-0.2879^{* * *}$ \\
\hline & $(0.08)$ & $(0.07)$ & $(0.07)$ & $(0.09)$ \\
\hline \multirow[t]{2}{*}{ Past school district performance (lagged 2 yrs) } & $0.1128^{\star \star \star}$ & $0.1130^{\star \star \star}$ & $0.1974^{\star \star \star}$ & $0.1381^{\star \star *}$ \\
\hline & $(0.04)$ & $(0.04)$ & $(0.04)$ & $(0.04)$ \\
\hline \multirow[t]{2}{*}{ Student density } & $-4.3935^{\star \star \star}$ & $-3.5640^{* \star *}$ & $-2.7522^{\star \star \star}$ & $-2.6573^{\star *}$ \\
\hline & $(1.29)$ & $(1.06)$ & $(0.70)$ & $(1.03)$ \\
\hline \multirow[t]{2}{*}{ Per Capita Personal Income } & 0.0891 & 0.0956 & 0.0990 & 0.0875 \\
\hline & $(0.15)$ & $(0.15)$ & $(0.14)$ & $(0.15)$ \\
\hline \multirow[t]{2}{*}{ Const. } & $67.7266^{\star * *}$ & $67.6595^{\star * \star}$ & $56.3318^{\star \star \star}$ & $67.4978^{\star \star \star}$ \\
\hline & $(8.11)$ & $(8.18)$ & $(7.76)$ & $(8.50)$ \\
\hline R squared & 0.68 & 0.62 & 0.65 & 0.61 \\
\hline Observations & 770 & 770 & 770 & 770 \\
\hline
\end{tabular}

Instead of the levels analysis presented above, the analysis below examines the effects of changes in student funding on the growth in student achievement. It is generally the case that spending per pupil was converging over the period of the analysis, such that the districts with the highest levels of spending growth were those with the lowest pre-policy spending and vice versa. Using a general value-added formulation similar to the example shown in Equation 1.1, the change in each grade level's mean percentile standardized test score was estimated using the change from one year to the next of peer, family, and school district inputs. Analysis of school 
districts with average or below average annual expenditure growth, those most likely to have high pre-policy spending, resulted in a positive and significant effect of growth of school expenditures on growth in student achievement for sixth and ninth grades (Table 2.7). The growth of expenditures was not shown to be a significant influence on academic achievement in third and eleventh grades. Other inputs were shown to affect each grade level differently with no significant effect by any variable on student achievement growth in grade eleven. This result indicates that student achievement in at least two grades could have been impacted by high levels of spending changes that occurred as a result of the legislative changes in public education finances in 1990 .

Table 2.7:

Determinants of Student Achievement in West Virginia: 1989-2002 Time and School District Fixed-Effects Model Full Dataset

(Dependant Variable: Change in Grade-Level Mean Standarized Score)

\begin{tabular}{|c|c|c|c|c|}
\hline & Grade 3 & Grade 6 & Grade 9 & Grade 11 \\
\hline Change in real school expenditures per & 0.0052 & $0.0494^{\star \star}$ & $0.0183^{*}$ & 0.0027 \\
\hline student $(\$ 1,000)$ & $(0.01)$ & $(0.02)$ & $(0.01)$ & $(0.01)$ \\
\hline \multirow[t]{2}{*}{ Change in \% Retained } & 0.0842 & 0.0309 & - & \\
\hline & $(1.63)$ & $(1.52)$ & & \\
\hline \multirow[t]{2}{*}{ Change in Pupil-teacher ratio } & 0.4034 & 0.1916 & 0.3313 & 0.2263 \\
\hline & $(0.40)$ & $(0.50)$ & $(0.41)$ & $(0.48)$ \\
\hline \multirow[t]{2}{*}{ Change in Average Teacher Experience } & -0.4998 & -0.4009 & -0.2901 & -0.0491 \\
\hline & $(0.33)$ & $(0.32)$ & $(0.28)$ & $(0.38)$ \\
\hline \multirow[t]{2}{*}{ Change in \% Poverity } & -0.2015 & $-0.3176^{\star}$ & $-0.2903^{\star *}$ & -0.2370 \\
\hline & $(0.17)$ & $(0.19)$ & $(0.14)$ & $(0.17)$ \\
\hline \multirow[t]{2}{*}{ Change in Past school district performance (lagged $2 \mathrm{yr}$ ) } & -0.0036 & -0.0014 & -0.0321 & -0.0449 \\
\hline & $(0.04)$ & $(0.04)$ & $(0.04)$ & $(0.05)$ \\
\hline \multirow[t]{2}{*}{ Change in Student density } & $-4.5151^{\star \star *}$ & $-3.2566^{\star}$ & $-2.0287^{\star}$ & -0.7963 \\
\hline & $(1.48)$ & $(1.84)$ & (1.13) & $(1.22)$ \\
\hline \multirow[t]{2}{*}{ Change in Per Capita Personal Income } & 0.1876 & 0.0623 & 0.1035 & -0.3394 \\
\hline & $(0.41)$ & $(0.28)$ & $(0.27)$ & $(0.32)$ \\
\hline \multirow[t]{2}{*}{ Const. } & 3.5814 & $-3.1753^{*}$ & 1.7855 & 2.0596 \\
\hline & $(2.20)$ & $(1.74)$ & $(1.43)$ & $(1.87)$ \\
\hline R squared & 0.48 & 0.38 & 0.32 & 0.24 \\
\hline Observations & 770 & 770 & 770 & 770 \\
\hline
\end{tabular}

\subsection{Conclusion}

The 1990 Appraisal Act in West Virginia created a more uniform property tax appraisal system within the state. Uniform practices coupled with revenue restricting legislation allowed for 
property tax revenue to rise. Rising property tax revenue led to an increase in the revenue base for funding public education. Equitable distribution practices of public education revenue, which included basing a majority of revenue on enrollment instead of actual costs, was promoted with the uniform property tax assessment practices. The increased funding for education was shown to have fundamentally different effects on different school districts and grade levels in West Virginia. Early economic research showed that increasing school resources had no effect on achievement and analysis of school districts that were characterized as having average or above average levels of expenditures per pupil prior to the policy change showed the same result. Growth in school resources was not shown to significantly increase the level of student achievement. School districts with below average pre-policy expenditure levels, however, were affected quite differently. Increased public education expenditures per pupil were shown to have a positive and statistically significant influence on student achievement in all four grade levels in West Virginia. While these effects were calculated to be rather small especially in comparison with average increases in funding from 1989 to 1990 there was clear evidence of their existence. These effects may be attributed to increased funding for new technologies, advanced courses, and better classroom resources. The argument that growth in inputs leads to growth in outputs, i.e. student achievement, was also supported in the analysis of all school districts. Increases in expenditures per student from one year to the next were shown to have positive and significant effect on growth of student achievement for grades six and nine in West Virginia.

In terms of policy applications, these results suggest that there might be important differences in the effects of spending on student achievement by sub-group. Namely, the results indicated that districts with low levels of pre-policy spending see an increase in the level of student achievement greater than districts with pre-policy levels of spending per student that are 
average or above average in the state. Additional research is needed to establish if there is a threshold point above which additional spending does not produce significantly higher test scores. 


\section{Chapter 3: How Important Are Excess Levies to Students?}

\subsection{Introduction}

Special property tax levies are implemented by school districts to raise funds above and beyond regular revenues. Tax levying bodies, in order to gain approval for the tax, assure voters that without these additional tax revenues educational standards within the district will not keep up with the rest of the state or nation. Educators also push for the passage of such additional revenues indicating that the difference between having and not having the extra monies is the difference between a "bare-bones" program and one that has a deep and lasting impact on the students.

The impact of additional revenues for public education on student achievement, however, has been widely debated. Initial research on the relationship between resources and student performance indicated that there is no impact of additional resources on achievement. As the topic has gained interest, studies have found a positive and significant relationship between public education expenditures and student performance. This paper will further this research through analysis of the passage of excess school levies and performance in West Virginia. Results show that revenues from excess levies in school districts that always have those additional levies did not significantly influence student achievement. Areas that sporadically passed public education excess levies did show a relationship between the school resources and student performance. These results lead to the notion that school districts with a long history of excess levies tend to get accustomed to those additional revenues while those school districts that do not consistently adopt excess levies use the additional monies to significantly influence the educational attainment of their students in all grade levels. 
This analysis will begin by reviewing the existing literature to determine what factors have been found to affect student achievement. The next step in the analysis will show the trends in property tax revenue from school excess levies across all fifty-five school districts in West Virginia. Comparisons of the level of regular public education revenue and excess levy revenue will indicate the importance of the additional funds to each school district. Characteristics of school districts that tend to pass public education excess levies will be explored. Analysis of a panel of standardized test scores at the district level for students in grades three, six, nine, and eleven will provide evidence of the importance of excess levy revenue on student performance in areas with and without additional revenues.

\subsection{Determinants of Academic Achievement}

The examination of the effects of school resources on student achievement began in 1966 with “The Coleman Report.” In his analysis, Coleman used school input variables such as pupil teacher ratio as well as family and other inputs in an education production function to determine what influences student achievement. Coleman concluded that family inputs not school inputs significantly influenced student achievement. Since the Coleman Report, an enormous amount of research has been devoted to the relationship between school inputs and academic output. Archibald (2006) found that expenditures per pupil must be disaggregated into more meaningful categories in order to show the true effects of school resources on educational attainment. Resources devoted to the learning experience such as classroom supplies, technology, and teachers have been shown to have a positive impact on student performance. In fact, Greenwald, Hedges, and Laine (1996) examined sixty research studies devoted to this relationship between expenditures and achievement and found that school resources are systematically related to 
achievement and that these relationships are large enough to be educationally important. They concluded that the most significant impacts occur from smaller class sizes.

This paper will expand on Chapter 2 by examining how the additional local school resources devoted to classroom supplies and teachers' wages instead of total resources increases affect student achievement on four grade levels. It will delve into whether school districts without additional local revenues have lower performance than areas that consistently have excess levies. Chapter 2 found that the equalizing of funding through the West Virginia Public School Support Program (PSSP) had a positive and significant impact on student achievement especially in areas with below average spending levels. This paper will expand on this research on student achievement determinants in West Virginia.

\subsection{West Virginia Data}

Analysis of the relationship between excess school revenue in the form of additional property taxes and student achievement in this paper will involve West Virginia district level data from 1992 to 2002 following education production function, instrumental variable and value-added methodologies. This analysis will involve the effect of additional revenues from public education excess levies on four different grade levels. The aforementioned research in this area only used one grade level and if multiple grade levels were analyzed only a few years of data was used.

Public education excess levies are additional property taxes levied by school district boards of education in West Virginia are and voted on by its constituency ${ }^{13}$. These excess levies may not extend beyond five years if approved by at least a majority of the voters. The rates of levy of public education excess levies cannot exceed the maximum rates for property taxes and

\footnotetext{
${ }^{13}$ West Virginia school district boards of education are also authorized to establish a permanent improvement fund and set a aside a portion of their regular property tax levy rates for permanent improvement purposes as well as issue bonds with majority vote in the district.
} 
must be proportional for all classes of property. Revenues collected through excess levies are used to provide free textbooks, teaching equipment and supplies, and supplement salaries and benefits for teachers and service personnel.

The measurement of student achievement in West Virginia school districts is in the form of mean standardized test scores for grades three, six, nine, and eleven from 1992 to 2002. Mean standardized test scores are for total basic skills and are the result of a statewide achievement testing program, which is mandated for public schools within the state. Students from 1992 to 2002 were tested for language, mathematics, reading, word analysis (in third grade only), study skills (in grades six, nine, and eleven), science and social studies.

The distribution of mean standardized test scores among excess levy and non-excess levy school districts shows a difference in average scores in all four grade levels (Figure 3.1). While differences in scores between excess levy school districts and non-excess levy districts is not as pronounced as in 2002, the distribution of standardized scores in 1992 shows a difference in grades three, six, and eleven. Ninth grade scores in 1992, however, were statistically similar at 56.3 and 56.5 for excess levy and non-excess levy districts respectively. In 2002, scores for total basic skills in all four grades were statistically higher in the excess levy school districts. In fact, scores in excess levy school districts were between seven and nine percent above scores of nonexcess levy school districts. 
Figure 3.1: Mean Standardized Test Score Distribution

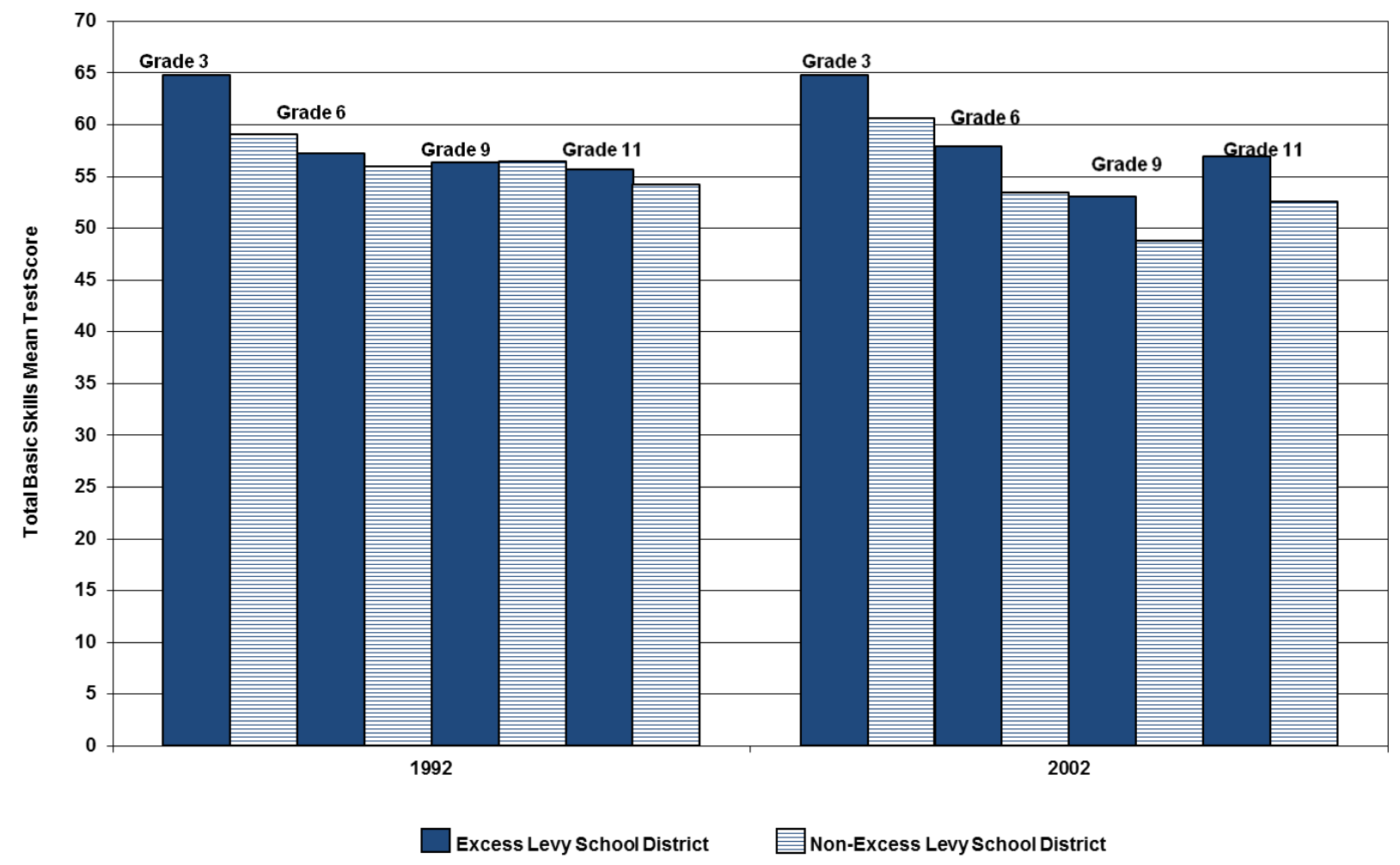

An examination of the standardized test scores of students in school districts that did not initially have an excess levy but eventually adopted an excess levy shows that additional classroom funds may have had an impact on achievement. Two school districts in West Virginia (Clay and Grant) did not adopt an excess levy until 1997. Figure 3.2 follows the students in these two school districts from $3^{\text {rd }}$ grade (when an excess levy was not in place) through the implementation of excess levy funds in their $6^{\text {th }}$ grade year and on through $11^{\text {th }}$ grade. Figure 3.2 compares this cohort of students with the achievement levels of students in school districts that continuously did or did not have an excess levy during this time span. Starting in 1994 in grade 3 , mean standardized test scores for students in school districts with an excess levy were the highest at an average of 67.4 percent, which corresponds to the results found in Figure 3.1. Scores in Clay and Grant were below average achievement levels in non-excess levy school 
districts and 9.5 percent below average scores in excess levy areas. In 1997, when these students were in $6^{\text {th }}$ grade, average achievement levels for excess levy school districts were still the highest while achievement levels in the two school districts who adopted an excess levy that year were higher than mean standardized test scores in non-excess levy school districts. After three years of receiving excess levy funds, average achievement levels in Clay and Grant school districts exceeded mean percentile standardized test scores in both excess and non-excess levy school districts by 2.5 percent and 10.4 percent respectively. This trend continued in this cohort's $11^{\text {th }}$ grade year. In the last year of funding from the excess levy that started in 1997, average student achievement in Clay and Grant school districts exceeded average achievement in excess levy and non-excess levy school districts by at least 7 percent.

Similar results are found for the students that were in the $9^{\text {th }}$ grade in Clay and Grant school districts when excess levies were adopted and funding from those levies began in 1997. In $6^{\text {th }}$ grade, prior to the adoption of public education excess levy, average scores in these two school districts were below excess levy school districts. However, by $11^{\text {th }}$ grade, which was two years into receiving excess levy funding, average scores in Clay and Grant exceeded achievement in other school districts. 


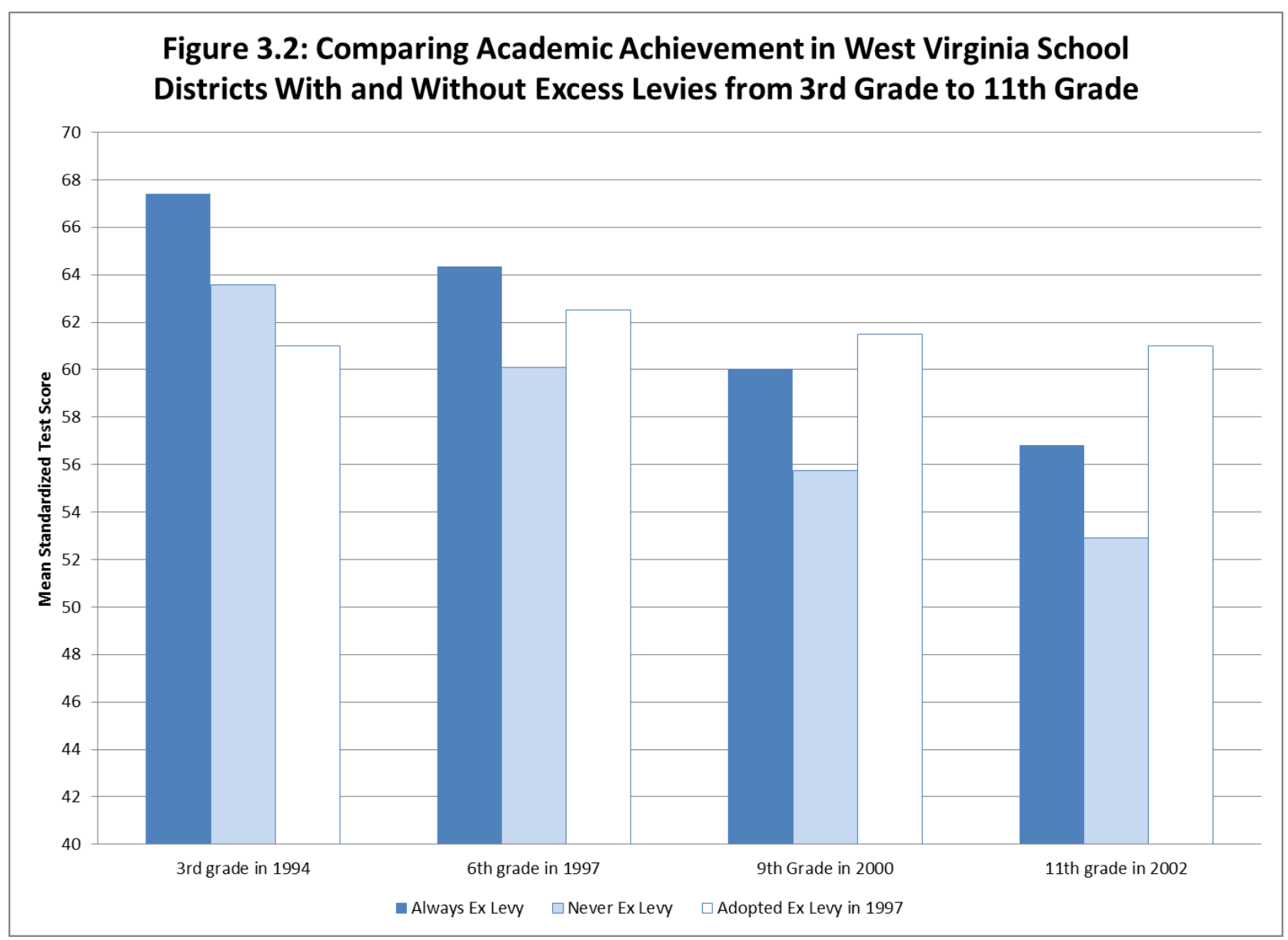

Public education resources or inputs have been measured in many difference forms.

Hanushek (2006) examined 376 education production function estimates that were published in 89 articles prior to 1995 all of which used education inputs such as teacher-pupil ratios, teacher education, and teacher experience. Hanushek concluded that adding more of these education resources may not boost student performance. The analysis in this paper will deviate from this previous research. Instead, public education resources will include inflation adjusted revenues ${ }^{14}$ per pupil for all fifty-five school districts in West Virginia from 1992 to 2002. Table 3.2 shows the average total real revenue per student was $\$ 6,407.38$ while average real excess levy revenue per student totaled $\$ 635.10$. Analysis will begin looking at the effect of real excess levy revenue

\footnotetext{
${ }^{14}$ Note due to balanced budget requirements, total revenues equal total expenditures. Revenues are inflation adjusted using 1990 as the base year.
} 
per pupil and all other real revenue per pupil on student achievement in school districts that continuously had excess levies from 1992 to 2002 and those school districts that gained or lost excess levies during this time period. Note that the excess levy revenues in West Virginia are used to provide free textbooks, additional classroom supplies including technology and additional teacher supplies and benefits. Thus, excess levy revenues can be characterized as additional instructional or classroom resources, which are considered to directly affect the level of education received by the students. Analysis will then look at all school districts in West Virginia from 1992 to 2002 using a value added and an instrumental variable regression technique.

Table 3.1: Summary Statistics West Virginia School Districts: 1992-2002 Full Dataset Mean (Standard Dev.)

\begin{tabular}{|l|c|c|c|c|}
\hline & Mean (Standard Dev.) & & & \\
\hline & Grade 3 & Grade 6 & Grade 9 & Grade 11 \\
\hline Mean Standarized Score & 63.8760 & 61.6397 & 57.6711 & 58.3670 \\
\hline & $(6.31)$ & $(6.31)$ & $(5.79)$ & $(5.81)$ \\
\hline All real revenues per student & $6,407.38$ & $6,407.38$ & $6,407.38$ & $(2823.92)$ \\
\hline & $(2823.92)$ & $(2823.92)$ & $(2823.92)$ & 635.10 \\
\hline Real excess levy revenues per student & 635.10 & 635.10 & 635.10 & $(546.56)$ \\
\hline Real other revenues per student & $(546.56)$ & $(546.56)$ & $(546.56)$ & $6,283.47$ \\
\hline & $6,283.47$ & $6,283.47$ & $6,283.47$ & $(1,315.91)$ \\
\hline Past school district performance (lagged 2 years) & $(1,315.91)$ & $(1,315.91)$ & $(1,315.91)$ & 57.8231 \\
\hline & 63.7620 & 61.1389 & 57.4744 & $(6.45)$ \\
\hline \% Retained & $(6.89)$ & $(6.92)$ & $(6.19)$ & - \\
\hline Pupil/Teacher Ratio & 1.6223 & 2.1784 & - & - \\
\hline Average teacher experience & $(0.23)$ & $(0.65)$ & - & 14.4707 \\
\hline & 14.4707 & 14.4707 & 14.4707 & $(0.96)$ \\
\hline \% Poverity & $(0.96)$ & $(0.96)$ & $(0.96)$ & 17.0474 \\
\hline Per Capita Personal Income (\$1,000) & 17.0474 & 17.0474 & 17.0474 & $(1.87)$ \\
\hline Student density (students per sq mile) & $(1.87)$ & $(1.87)$ & $(1.87)$ & 25.5581 \\
\hline Percent of population over 65 years & 25.5581 & 25.5581 & 25.5581 & $(7.95)$ \\
\hline & $(7.95)$ & $(7.95)$ & $(7.95)$ & 17.64 \\
\hline
\end{tabular}

Immense research has been devoted to the importance of inputs outside of public education resources on student achievement and performance. For example, studies have 
addressed the effects of class size (Hoxby 2000; Urquiola and Verhoogen 2009), health (GurleyCalvez and Higginbotham 2009), peers (Hanushek et al 2003), parental effort (Houtenville and Conway 2008), and teacher quality (Aaronson, Barrow, and Sander 2007; Clotfelter, Ladd, and Vigdor 2007). Analysis of the effects of additional school resources from excess school levies will include explanatory variables for the effects of peers, family income, and school district characteristics.

Peer inputs, which have been shown to have positive and significant effects on student achievement, will be captured using retention rates ${ }^{15}$ for each grade level and expressed as a percentage of enrolled students that were held back a year or retained. These rates demonstrate the number of students in each grade level that did not meet qualifications to be promoted to the next grade level at the end of the school year.

To capture the effects of education resources outside of public education revenues, school district level data on pupil-teacher ratios and average educational experience for teachers were collected. Pupil-teacher ratios, which are calculated by dividing net enrollment in each school district by the number of full-time equivalent (FTE) teachers, measure average class size and can indicate over or under crowded classrooms. From 1992 to 2002, the average pupil-teacher ratio was 14.47 (Table 3.1). Average teacher experience is estimated by dividing the sum of all years of experience of teachers in each school district by the number of teachers employed in each district.

Results of "The Coleman Report" showed that families are one of the key elements to student success. To capture the resources of the families of students in each grade level from 1992 to 2002, estimates of low income levels for families were included within the production

\footnotetext{
${ }^{15}$ Due to data availability, student retention rates were not available for grades 9 and 11. Dropout rates for these grades were considered but after further examination were not used due to a change in how dropout rates were calculated during the 1995-1996 school year.
} 
function analysis. Variables considered as an estimate of family influence included the number of students eligible for free or reduced lunch and the number and percentage of five to seventeen year olds from families in poverty. To qualify for free or reduced price lunch, family characteristic qualifications for each child must be met. These qualifications, which include size of household and level of household income, are adjusted annually. The percentage of students qualifying for free and reduced lunch and the percentage coming from families in poverty are highly correlated thus, due to explanatory power in the regression results; the percentage of children in impoverished families was used. The percentage of West Virginia students living in impoverished families during this time period was 25.6 percent (Table 3.1).

The characteristics of the surroundings in which students live can also be argued to have an effect on student achievement. To account for these possible affects, school district ${ }^{16}$ characteristics were included in the analysis. Expected achievement levels for current students in each of the four grades in each school district were measured using mean standardized test scores lagged two years. These lagged achievement scores can indicate the impact of not only the expectations for achievement but also the quality of teachers and other classroom resources on current achievement levels. The level of urbanization or lack thereof was captured by density rates. Density was calculated as the number of students enrolled in grades three, six, nine and eleven per square mile of the school district for which they were enrolled. Thus, third grade student density for each school district is equal to the number of students enrolled in grade three in that district for that school year per square mile of that county. From 1992 to 2002, average third grade student density in West Virginia was 1.1 third graders per square mile (Table 3.1). Population levels and personal income per capita levels were also considered as explanatory variables. However, in final analysis, only per capita personal income of each school district

\footnotetext{
${ }^{16}$ West Virginia school districts are defined by county borders.
} 
from 1992 to 2002 was found to have an effect on student achievement. Racial characteristics were not included in this analysis due to the homogeneity of the population within West Virginia during this time period. On average, enrollment in West Virginia school districts is 94 percent white, five percent African American, and one percent Hispanic, Indian, or Asian and this remains the trend throughout the 1992 to 2002 time period.

\subsection{Characteristics of West Virginia Excess Levy School Districts}

From 1992 to 2002, of the fifty-five school districts, 39 to 43 districts ${ }^{17}$ within West Virginia imposed a school excess levy each year. Voters in eleven school districts never passed public education excess levies during this time period. Figure 3.3 shows the distribution of excess levy school districts and non-excess levy districts throughout the state. Note that a majority of the school districts or counties located within the mountainous and rural areas of the state tend to not have excess school levies. School districts that sporadically pass school excess levies are also located in the more mountainous parts of the state.

\footnotetext{
${ }^{17}$ Thirty-nine school districts imposed an excess levy each year while 5 others had a levy sporadically during this time period.
} 
Figure 3.3: School Excess Levy Distribution in West Virginia

1992-2002

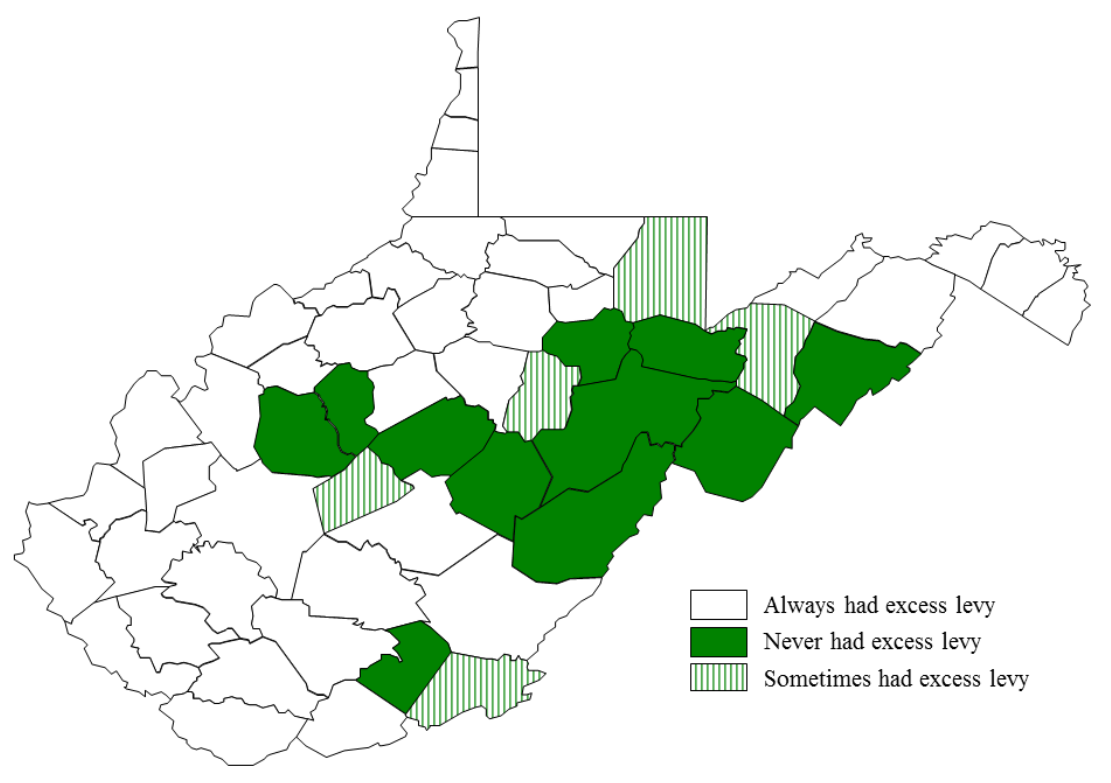

While non-excess levy school districts tend to be geographically homogenous they also have similar demographic characteristics. Figure 3.4 shows the distribution of residents 65 years of age or older. All school districts that do not have excess school levies, except Roane County, have above state average percent of the population 65 years old and above. Individuals in this age category tend to have exceptional voting records, no longer have children in the public school system, have fixed incomes, and thus may be a factor in the failure of an excess school levy vote. 
Figure 3.4: Percentage of Population Over 65 Years of Age in West Virginia

1992

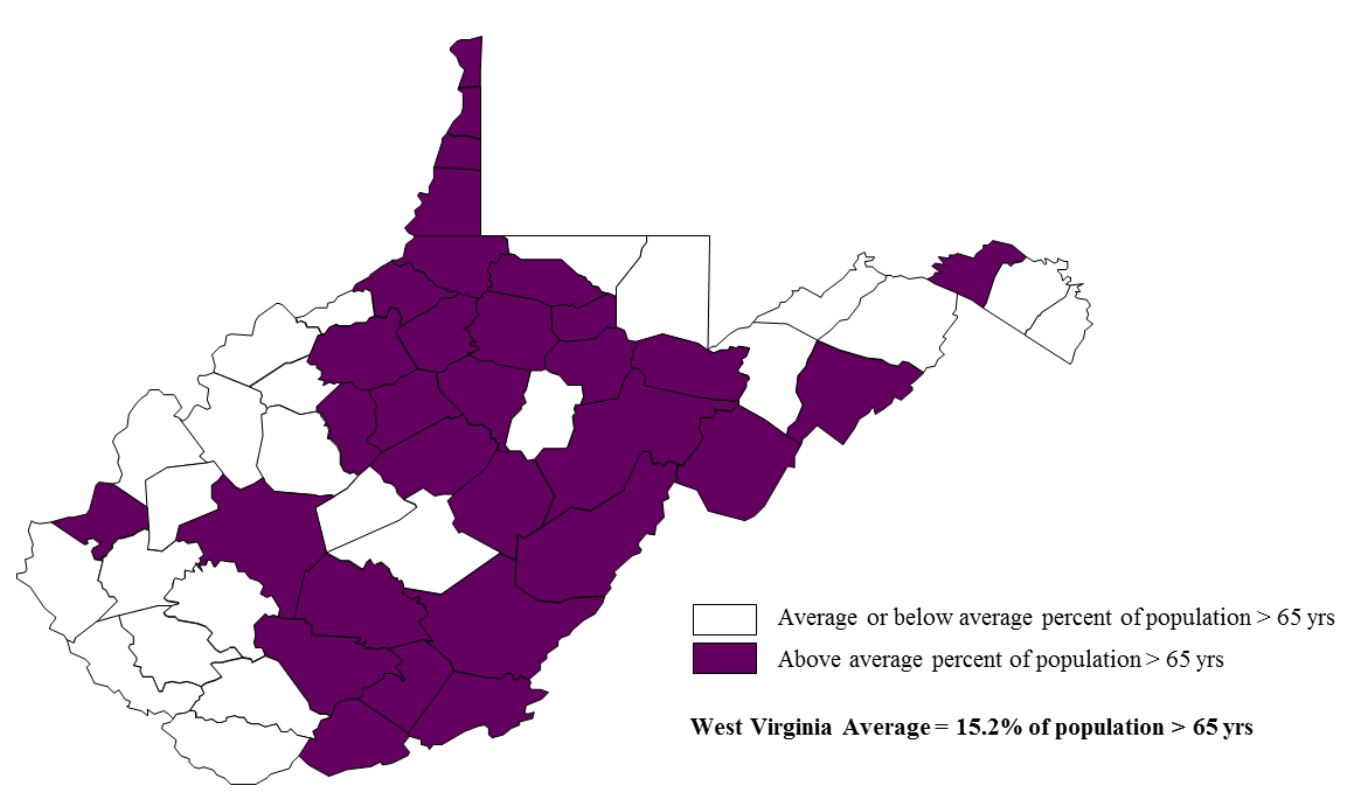

The correlation between income levels and passage of excess school levies in West Virginia during this time period is also apparent. Only three school districts where excess levies are not prevalent have average or above average personal income per capita in 1992 (Figure 3.5). The eight remaining school districts have below average personal income per capita. These results are consistent throughout the entire time period. 


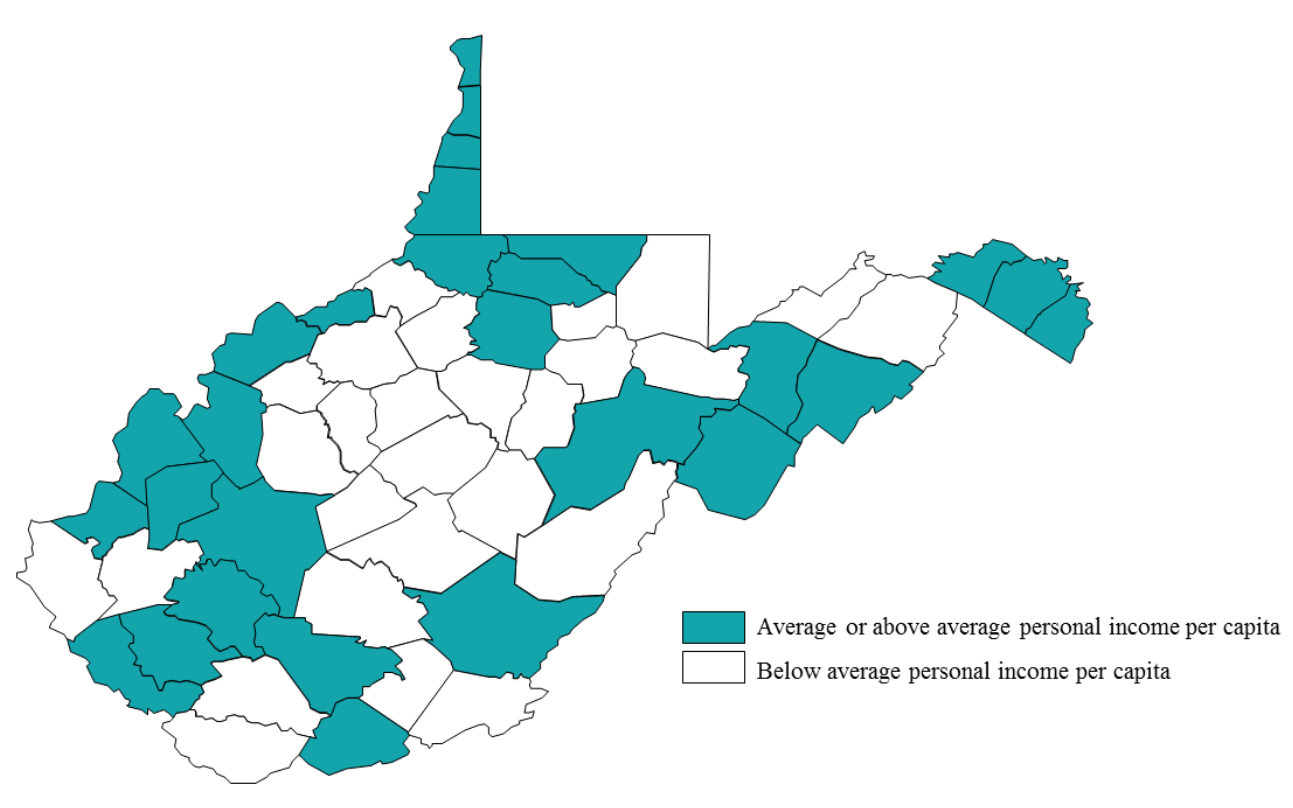

Figures 3.3, 3.4, and 3.5 show that the school districts that tend to not pass public education excess levies are located in the more mountainous areas of West Virginia, have higher levels of their population at retirement age, and below average personal income per capita. Using a probit model shown in Equation 3.1, the characteristics that tend to influence if a school district in West Virginia adopts an excess levy were identified. The probit regression model used showed the marginal effects of changes in each independent variable on the change in the probability for excess levy revenue to be collected in a school district.

Equation 3.1:

$\operatorname{Pr}\left(\right.$ SchoolDistrict $_{\mathrm{i}}=$ ExcesslevyDistrict $\left._{\mathrm{i}}\right)=\mathrm{f}\left(\right.$ Score $_{\mathrm{i}}$, Revenues $_{\mathrm{i}}$, Peer $_{\mathrm{i}}$, Family $_{\mathrm{i}}$, District $\left._{\mathrm{i}}\right)+\varepsilon_{\mathrm{i}}$ 
Results of the probit model indicate that the assumptions made from Figures 3.3 and 3.4 were correct (Table 3.2). An increase in the level of urbanization, measured as the number of students per square mile, significantly increases the probability of a school district adopting an excess levy. This result is consistent with Figure 3.3, which showed that school districts located in the more populated areas of the state tend to continuously adopt excess levies for public education. An increase in the percentage of the population in retirement age category (65 years old and older) has a significant and negative influence on the adoption of a school excess levy. A one percentage point increase in the percentage of the population in this age category decreases the probability that a school district votes for an excess levy by 4 to 6 percentage points. The number of children residing in an impoverished household also has a negative influence on the probability a school district will pass an excess levy while increased student achievement at all grade levels has the opposite effect.

Table 3.2:

Probability of Having an Excess Levy in West Virginia: 1992-2002 Marginal Probit Model Full Dataset (Dependant Variable: Excess Levy Dummy)

\begin{tabular}{|c|c|c|c|c|}
\hline & Grade 3 & Grade 6 & Grade 9 & Grade 11 \\
\hline \multirow[t]{2}{*}{ Mean Standarized Score } & $3.54^{\star \star \star}$ & $2.35^{\star \star \star}$ & $1.91^{* * *}$ & $2.91^{\star \star \star}$ \\
\hline & $(0.03)$ & $(0.03)$ & $(0.03)$ & $(0.01)$ \\
\hline \multirow[t]{2}{*}{ All revenues per student $(\$ 1,000)$} & 0.85 & 1.11 & 1.57 & $1.66^{\star * *}$ \\
\hline & $(0.76)$ & $(0.82)$ & $(1.09)$ & $(0.09)$ \\
\hline \multirow[t]{2}{*}{$\%$ Retained } & 0.74 & 0.23 & - & - \\
\hline & $(1.50)$ & $(1.10)$ & & \\
\hline \multirow[t]{2}{*}{$\%$ Poverity } & $-3.10^{\star \star *}$ & $-2.42^{\star \star \star}$ & $-2.10^{* * *}$ & $-2.69^{* * *}$ \\
\hline & $(0.02)$ & $(0.03)$ & $(0.03)$ & $(0.03)$ \\
\hline \multirow[t]{2}{*}{ Per Capita Personal Income } & 0.74 & 0.35 & 1.49 & 0.88 \\
\hline & $(0.81)$ & $(0.78)$ & $(0.95)$ & $(0.69)$ \\
\hline \multirow[t]{2}{*}{ Past School District Performance (lagged 2 yrs) } & $3.48^{\star * \star}$ & $1.37^{\star \star *}$ & -0.51 & -0.45 \\
\hline & $(0.02)$ & $(0.02)$ & $(0.02)$ & $(0.01)$ \\
\hline \multirow[t]{2}{*}{ Student density } & $8.71^{\star \star \star}$ & $9.28^{* \star *}$ & $8.53^{\star \star \star}$ & $9.79^{* \star *}$ \\
\hline & $(1.79)$ & $(2.34)$ & $(2.67)$ & $(2.30)$ \\
\hline \multirow[t]{2}{*}{$\% 65$ plus } & $-5.71^{\star \star *}$ & $-5.47^{\star \star \star}$ & $-4.11^{\star \star \star}$ & $-4.03^{\star \star \star}$ \\
\hline & $(0.01)$ & $(0.01)$ & $(0.01)$ & $(0.01)$ \\
\hline Pseudo R squared & 0.46 & 0.42 & 0.41 & 0.42 \\
\hline Observations & 605 & 605 & 605 & 605 \\
\hline
\end{tabular}


Average excess levies per pupil in West Virginia ranged from \$589 in 1992 to $\$ 1,021$ in $2002^{18}$ (Figure 3.6). These excess levies consistently grew each year with the exception of a spike and decline around 1994. During the 1994-1995 school year average excess levy revenues exceeded $\$ 900$ per pupil in the 39 school districts with excess levies. This significant increase in average revenues per pupil was attributable to the failure of excess school levy elections in two school districts ${ }^{19}$. These two school districts had substantially low excess levy revenues prior to 1994. The subsequent decline in 1995 was a result of one of those school districts passage of the excess levy. The consistent increase in average excess levies for school districts throughout this time period was due to increases in assessed valuations of residential and business property throughout the state. From 1992 to 2002, assessed valuations in which school excess levies were based on increased by approximately 87 percent (Higginbotham, Gurley-Calvez, Sen 2009).

\footnotetext{
${ }^{18}$ Excess levies per pupil are shown in nominal terms in Figure 3.7 but for analysis excess levy revenue is adjusted for inflation.

${ }^{19}$ School districts that did not renew their excess levy for the 1994-1995 school year included Monroe and Preston counties. These counties had some of the lowest excess levy revenues per pupil in the previous year. Monroe County's excess levy per pupil was, in fact, the lowest at \$231 per pupil during the 1993-1994 school year. Monroe County reinstated its school excess levy in 1995-1996, where it was once again the lowest in the state per pupil.
} 


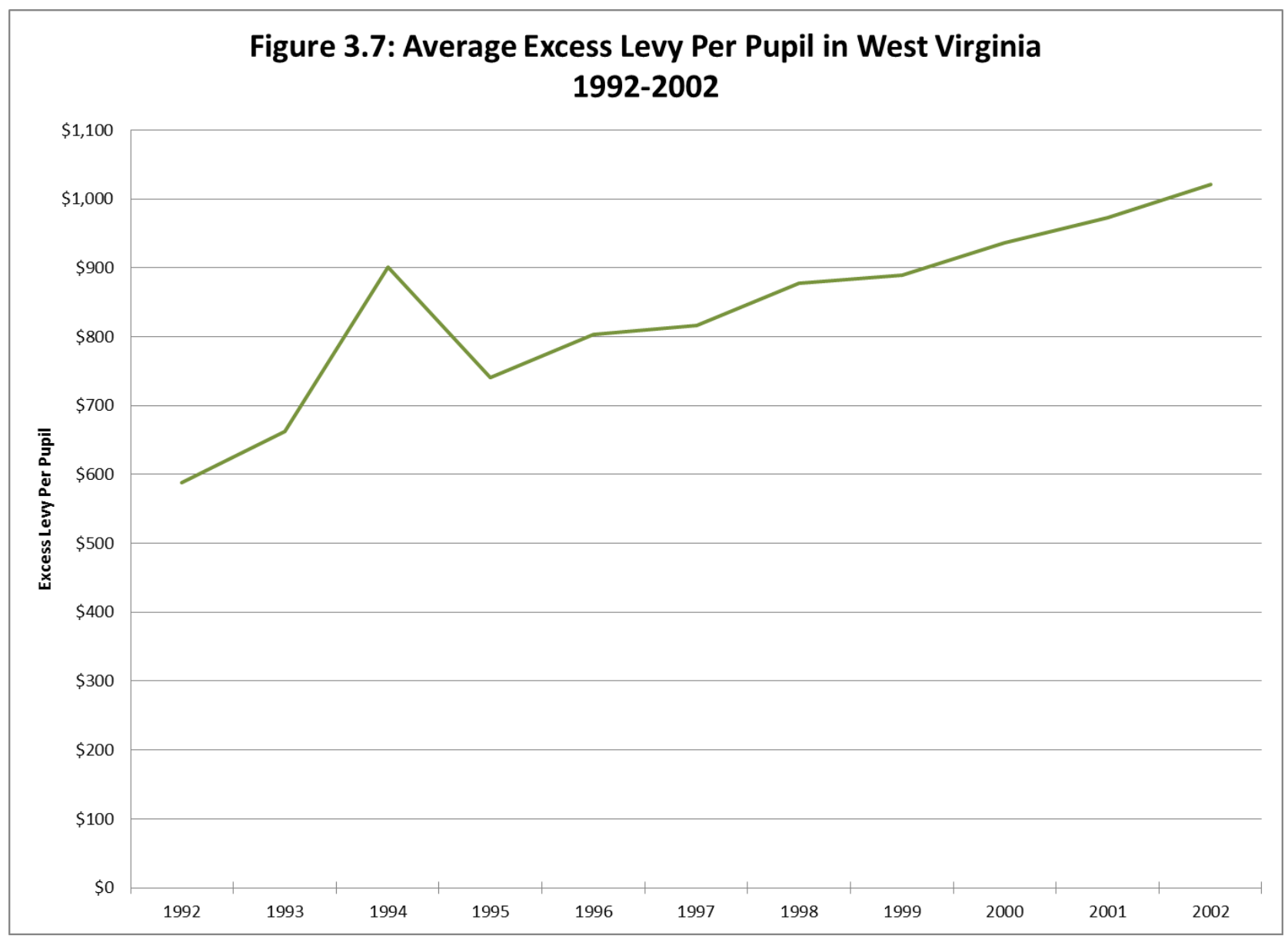

School districts that have passed school excess levies are presumed to correspondingly have revenues per pupil at levels higher than areas without such levies. This assumption holds true in school districts in West Virginia from 1992 to 2002 except during two school years, as shown in Figure 3.8. Average total revenues per pupil in non-excess levy districts is higher than for districts with excess levies as well as the state average for 1992 and 1998. During those two school years, federal revenues per pupil where exceedingly higher in the districts without special excess levies. Average federal revenue per pupil in non-excess levy school districts was approximately 33 percent higher than in the districts with excess levies. 


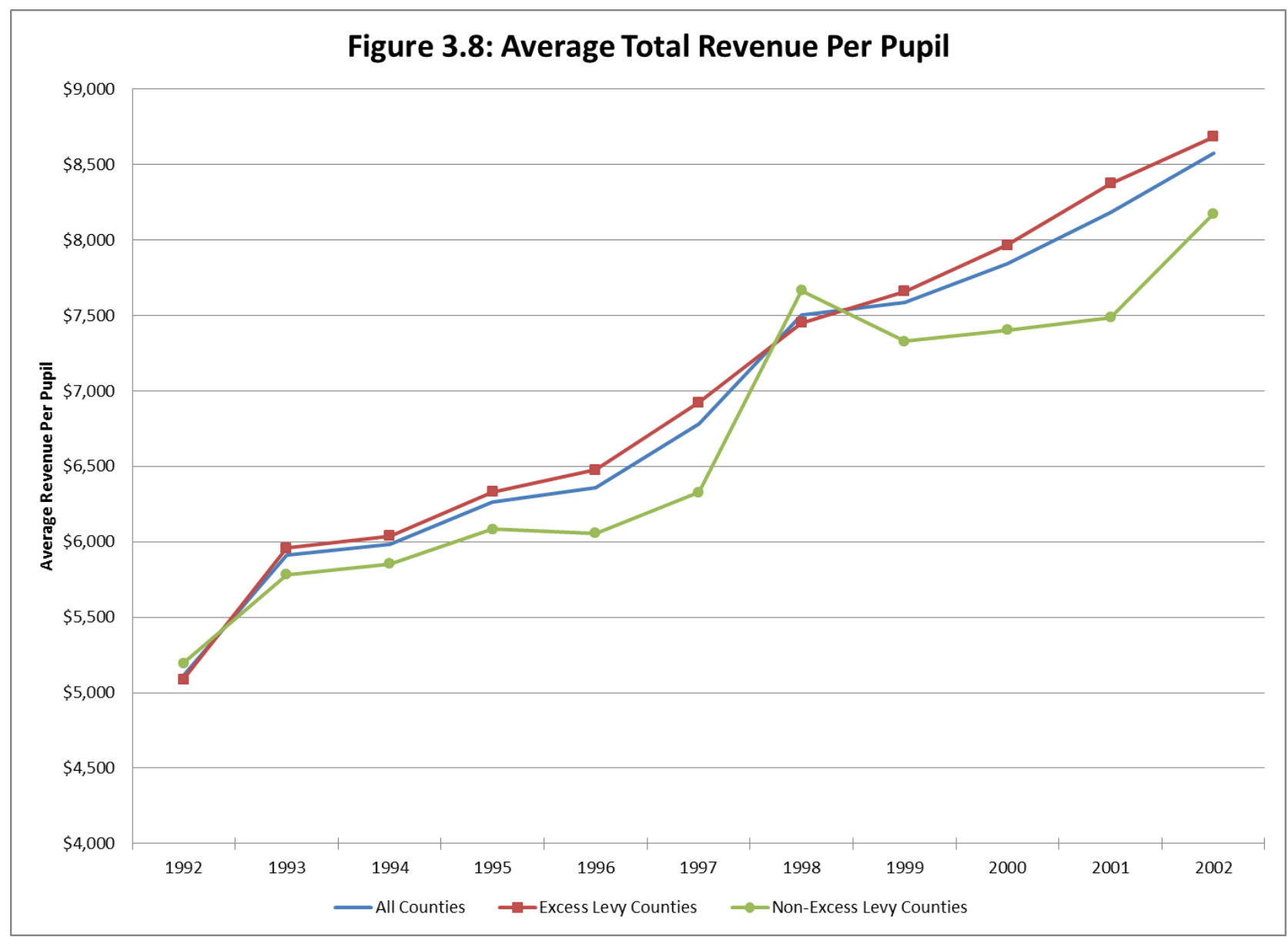

From 1992 to 2002, changes to the public education system in West Virginia may have had an impact on the public education excess levies. Public education funding in West Virginia was significantly altered by the passage of the 1990 Appraisal Act and the implementation of the PSSP. $^{20}$ The goal of this transformation was to allocate property tax revenue for public education in an equitable manner. Property taxes were to be assessed in each school district at 60 percent of fair market value and 98 percent of the monies collected from property taxes for education would be collected by the state and reallocated to the school districts based on net enrollments and fixed costs. During this transformation to a more equitable funding system for public education, school districts in the state continued to have the ability to pass excess levies to fund public education.

\footnotetext{
${ }^{20}$ More information can be found in Chapter 2.
} 
Figure 3.9 shows that the passage of the 1990 Appraisal Act and the movement toward more equitable public funding across West Virginia school districts did not have a significant effect on the number of excess levies passed. Prior to this legislation 14 school districts did not have an excess levy. After 1990, the number of non-excess levy school districts remained between 12 and 16 through 2002.

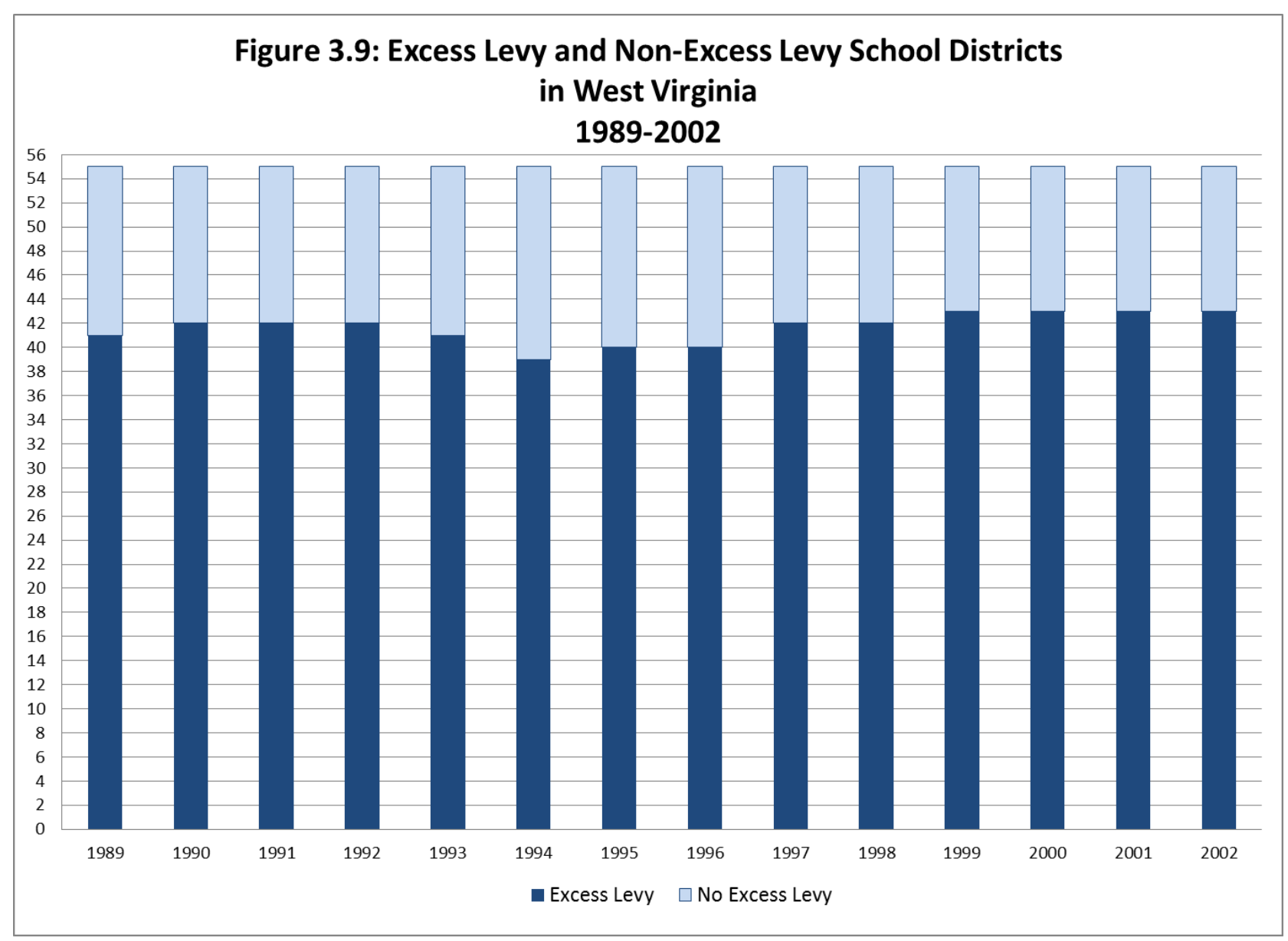

\subsection{Effect of Excess Levy Revenue on Student Achievement}

Analysis of the relationship between excess levies and student achievement began by examining whether there is an association between total school resources, excess levy resources, and 
academic achievement at the district level for school districts that continuously or sporadically adopted excess levies. Education production function analysis in conjunction with time and school district fixed effects was used. Student mean percentile scores for each grade level were the dependent variables in this fixed effect model while peer, family, and school district inputs were factored into the OLS regression analysis, as shown in Equation 3.2:

Score $_{i t}=\mathrm{f}\left(\right.$ Ex. Revenues $_{\mathrm{it}}$, OtherRevenues $_{\mathrm{it}}$, Peer $_{\mathrm{it}}$, Family $_{\mathrm{it}}$, District $\left._{\mathrm{it}}\right)+\tau_{\mathrm{it}}+\rho_{\mathrm{it}}+\varepsilon_{\mathrm{it}}$ where Ex.Revenues include real excess levy revenues per pupil for each year and OtherRevenues includes all real revenues per pupil other than those captured by the ExRevenues and where $\mathrm{i}$ indicates school district and t denotes time. Time and school district fixed effects are denoted by $\tau$ and $\rho$ respectively while $\varepsilon$ indicates white noise.

Analysis using Equations 3.2 is subject to potentially serious omitted variable bias as it does not include factors from earlier periods that could have cumulative effects on student performance. To alleviate this potential problem, value added production function analysis was performed for school districts that consistently had an excess levy and those school districts that sporadically had an excess levy during this time period. This type of analysis included the use of a previous test score as a measure of the accumulation of knowledge and resources up to that grade level. Since West Virginia begins testing students at grade three, value added analysis was restricted to grades six, nine, and eleven. For each of these three grade levels, lagged test scores included third grade scores for grade six, sixth grade scores for grade nine, and ninth grade scores for grade eleven.

Instrumental variable (IV) regression analysis was also performed to help deal with a potential omitted variable bias and endogenity issue in the model as well as low levels of change in real excess levy revenues per pupil. The probit analysis showed that increasing the percentage 
of the population that is over 65 years of age statistically decreases the probability that a school district will adopt a public education excess levy. Due to the effect of this age group on voting for excess levies, an IV approach was taken to estimate the effect of real excess levy revenues per pupil on student achievement on all school districts in West Virginia from 1992 to $2002 .^{21}$ For the IV model, student achievement scores are modeled as a function of peer, family, and school district inputs including real excess levy revenue per student, while instrumenting for having real excess levy revenue using the percentage of population 65 years old or older (Equation 3.3 and 3.4).

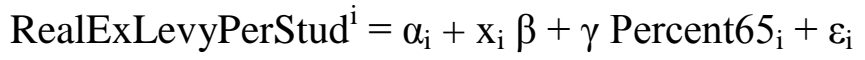

Score $_{i}=\lambda_{i}+x_{i} \varsigma+\xi$ RealExLevyPerStud $_{i}+\mu_{i}$

where $\varsigma$ includes peer, family, and school district inputs and $\varepsilon$ and $\mu$ are error terms; I denotes each school district.

Analysis of the West Virginia school districts that consistently had an excess levy from 1992 to 2002, results, presented in Table 3.3, indicate that real excess levy revenues per student were not shown to have a significant effect on student achievement. Using OLS time and school district fixed effects model, real excess levies were not shown to have a significant effect on mean standardized test percentiles at any grade level. This result supports the assumption that school districts that have a long history of having additional funds from excess levies tend to become reliant on those monies thus use them for the same instructional resources each year. In a time and school district fixed effects model, like this one, the excess levy revenue for the school districts that continuously have an excess levy does not significantly change so there is not an

\footnotetext{
${ }^{21}$ Hausman test of over-identifying restrictions was completed using STATA's ivreg2 (Baum, et al, 2010). This test indicated that the percentage of population 65 years of age and older significantly affects the probability that a school district would receive excess levy revenue but does not appear to affect student achievement. Therefore, this variable should be appropriate identifying variable.
} 
effect found on student achievement. Only the independent variables that changed over time and from school district to school district had an effect. Consistent with the results in Chapter 2, past achievement in the school district, which measures academic expectations and resource quality in the district, had a positive influence on student performance at all grade levels while poverty levels were revealed to have a negative effect in grades 9 and 11 . The level of urbanization, measured by the number of students per square mile for each grade level, had a negative but significant impact on grades 3, 9, and 11 in the school districts that consistently had an excess levy from 1992 to 2002 .

Table 3.3:

Determinants of Student Achievement in West Virginia: 1992-2002 Time and School District Fixed-Effects Model School Districts Always With Excess Levy (Dependant Variable: Grade-Level Mean Standarized Score)

\begin{tabular}{|c|c|c|c|c|}
\hline & Grade 3 & Grade 6 & Grade 9 & Grade 11 \\
\hline \multirow[t]{2}{*}{ Real excess levy revenues per student $(\$ 1,000)$} & 0.0206 & 0.0467 & 0.0552 & 0.0263 \\
\hline & $(0.06)$ & $(0.05)$ & $(0.03)$ & $(0.06)$ \\
\hline \multirow[t]{2}{*}{ All other real revenues per student $(\$ 1,000)$} & 0.0339 & 0.0112 & 0.0333 & 0.0238 \\
\hline & $(0.03)$ & $(0.03)$ & $(0.02)$ & 0.04 \\
\hline \multirow[t]{2}{*}{$\%$ Retained } & -0.0122 & -0.0128 & - & - \\
\hline & $(0.01)$ & $(0.01)$ & - & - \\
\hline \multirow[t]{2}{*}{$\%$ Poverity } & -0.0785 & 0.0102 & $-0.2414^{\star \star}$ & $-0.3271^{* * *}$ \\
\hline & $(0.12)$ & $(0.13)$ & $(0.10)$ & $(0.11)$ \\
\hline \multirow[t]{2}{*}{ Past School District Performance (lagged 2 yrs) } & $0.1108^{*}$ & $0.0995^{\star}$ & $0.0977^{\star *}$ & $0.1729^{* * *}$ \\
\hline & $(0.06)$ & $(0.06)$ & $(0.04)$ & $(0.04)$ \\
\hline \multirow[t]{2}{*}{ Per Capita Personal Income } & $0.3858^{* *}$ & -0.1356 & -0.1342 & 0.0664 \\
\hline & $(0.18)$ & $(0.19)$ & $(0.16)$ & $(0.15)$ \\
\hline \multirow[t]{2}{*}{ Student density } & $-5.3941^{\star * *}$ & -1.0930 & $-2.3906^{\star * *}$ & $-1.9563^{\star}$ \\
\hline & $(1.84)$ & $(1.47)$ & $(0.74)$ & $(1.16)$ \\
\hline \multirow[t]{2}{*}{ Pupil/teacher ratio } & -0.3133 & 0.0571 & 0.0229 & -0.1700 \\
\hline & $(0.49)$ & $(0.48)$ & $(0.35)$ & $(0.39)$ \\
\hline \multirow[t]{2}{*}{ Average Teacher Experience } & -0.0678 & -0.0412 & -0.0927 & -0.1700 \\
\hline & $(0.28)$ & $(0.33)$ & $(0.30)$ & $(0.39)$ \\
\hline \multirow[t]{2}{*}{ Const. } & $86.8036^{\star \star \star}$ & $63.4470^{\star * *}$ & $66.5009^{* * *}$ & $67.2982^{* * *}$ \\
\hline & $(13.60)$ & $(12.93)$ & $(10.42)$ & $(11.73)$ \\
\hline R squared & 0.69 & 0.62 & 0.71 & 0.68 \\
\hline Observations & 429 & 429 & 429 & 429 \\
\hline
\end{tabular}

In school districts that sporadically adopted public education excess levies, real excess levy revenue per pupil is shown to have a significant and positive impact on achievement (Table 3.4). For all four grade levels, an increase of $\$ 1,000$ of real excess levy revenue per student 
increased mean standard percentile scores by between 0.62 and $0.88 .^{22}$ This result supports the theory that adding additional instructional or classroom resources to a school district not reliant on those resources can have a positive impact on student achievement. For the school districts in West Virginia that continuously do not adopt public education excess levies, this result could help influence voters to adopt an excess levy to increase the education achievement in their school district.

Consistent with the results in Table 3.3 and Chapter 2, past performance in the school district had a positive and significant effect on mean standardized test score for all four grade levels while student density had a negative effect (Table 3.4). The percentage of children in impoverished families had a negative effect on student achievement levels in grades 9 and 11 .

Table 3.4:

Determinants of Student Achievement in West Virginia: 1992-2002 Time and School District Fixed-Effects Model School Districts Sometimes With Excess Levy (Dependant Variable: Grade-Level Mean Standarized Score)

\begin{tabular}{|l|c|c|c|c|}
\hline & Grade 3 & Grade 6 & Grade 9 & Grade 11 \\
\hline Real excess levy revenues per student $(\$ 1,000)$ & $0.8799^{* *}$ & $0.8103^{* *}$ & $0.6211^{*}$ & $0.8413^{*}$ \\
\hline & $(0.42)$ & $(0.40)$ & $(0.33)$ & $(0.44)$ \\
\hline All other real revenues per student $(\$ 1,000)$ & 0.1110 & 0.1618 & 0.0888 & 0.0934 \\
\hline \% Retained & $(0.09)$ & $(0.11)$ & $(0.11)$ & $(0.13)$ \\
\hline & -0.0005 & -0.0002 & - & - \\
\hline \% Poverity & $(0.01)$ & $(0.01)$ & - & -0.1585 \\
\hline & -0.0336 & $-0.7505^{*}$ & $-0.5404^{\star *}$ & $(0.37)$ \\
\hline Past School District Performance (lagged 2 yrs) & $(0.36)$ & $(0.43)$ & $(0.25)$ & $0.3365^{\star}$ \\
\hline Per Capita Personal Income & $0.3501^{*}$ & $0.3398^{*}$ & $0.3413^{*}$ & $(0.20)$ \\
\hline & $(0.18)$ & $(0.17)$ & $(0.18)$ & 0.4684 \\
\hline Student density & -0.3417 & 0.0551 & $1.6698^{* * *}$ & $(0.52)$ \\
\hline Pupil/teacher ratio & $(0.51)$ & $(0.47)$ & $(0.48)$ & 1.2843 \\
\hline Average Teacher Experience & -1.7980 & -1.4167 & -1.4100 & $(2.48)$ \\
\hline Const. & $(2.00)$ & $(1.85)$ & $(1.15)$ & 0.6486 \\
\hline R squared & 0.8231 & 0.9812 & 0.6433 & $(1.40)$ \\
\hline Observations & $(1.43)$ & $(2.09)$ & $(1.16)$ & -0.5254 \\
\hline
\end{tabular}

Note: Percent of retained student for 9 th and 11 th grades were not available. Robust standard errors are shown in parentheses. Significance levels: ${ }^{* \star \star}$ at $1 \%$, ${ }^{\star \star}$ at $5 \%$, and * at $10 \%$.

\footnotetext{
${ }^{22}$ Note: an increase of $\$ 1,000$ per pupil in excess levy revenue is considerably high during this time period when the average annual increase in excess levy revenue per pupil was approximately $\$ 43$.
} 
Table 3.5 examines the input factors that may influence mean standardized test scores for all 55 school districts in West Virginia from 1992 to 2002 including an estimator for the accumulation of knowledge and resources. This estimator helps deal with potential omitted variable bias. Regression analysis using this estimator in addition to the other input factors from Tables 3.3 and 3.4 for grades 6, 9, and 11 show that previous academic performance of children currently in the school district had a positive impact on current levels of achievement (Table 3.5). For instance, previous academic achievement for $6^{\text {th }}$ graders, measured as the mean standardized test score those children received in $3^{\text {rd }}$ grade, had a positive and significant effect on their academic performance in $6^{\text {th }}$ grade. This result concludes that previous performance has a cumulative effect on achievement in all grade levels while the percentage of children in poverty had a negative influence on achievement in grades 9 and 11. 
Table 3.5:

Determinants of Student Achievement in West Virginia: 1992-2002 Time and School District Fixed-Effects Model with Accumulated Knowledge Full Database

(Dependant Variable: Grade-Level Mean Standarized Score)

\begin{tabular}{|c|c|c|c|}
\hline & Grade 6 & Grade 9 & Grade 11 \\
\hline \multirow[t]{2}{*}{ Real excess levy revenues per student $(\$ 1,000)$} & 0.0171 & 0.0362 & 0.0280 \\
\hline & $(0.05)$ & $(0.03)$ & $(0.06)$ \\
\hline \multirow[t]{2}{*}{ All other real revenues per student $(\$ 1,000)$} & 0.0199 & 0.0275 & 0.0220 \\
\hline & $(0.03)$ & $(0.02)$ & $(0.03)$ \\
\hline \multirow[t]{2}{*}{ Accumulated knowledge (previous test score) } & $0.2502^{* \star *}$ & $0.1274^{\star *}$ & $0.1258^{* *}$ \\
\hline & $(0.06)$ & (0.05) & $(0.05)$ \\
\hline \multirow[t]{2}{*}{$\%$ Retained } & -0.0012 & - & - \\
\hline & $(0.01)$ & - & - \\
\hline \multirow[t]{2}{*}{ Past school district performance (lagged 2 yrs) } & $0.0182^{*}$ & $0.0743^{*}$ & $0.1495^{\star *}$ \\
\hline & $(0.01)$ & $(0.04)$ & $(0.06)$ \\
\hline \multirow[t]{2}{*}{$\%$ Poverity } & -0.0408 & $-0.2303^{* *}$ & $-0.2915^{\star *}$ \\
\hline & $(0.13)$ & $(0.09)$ & $(0.11)$ \\
\hline \multirow[t]{2}{*}{ Per Capita Personal Income } & 0.1692 & -0.1172 & 0.1009 \\
\hline & $(0.19)$ & $(0.16)$ & $(0.15)$ \\
\hline \multirow[t]{2}{*}{ Student density } & -0.2568 & $2.2749^{* \star \star}$ & -0.8210 \\
\hline & $(1.52)$ & $(0.74)$ & $(1.14)$ \\
\hline \multirow[t]{2}{*}{ Pupil/teacher ratio } & $0.7677^{*}$ & 0.1301 & -0.5352 \\
\hline & $(0.46)$ & $(0.35)$ & $(0.39)$ \\
\hline \multirow[t]{2}{*}{ Average Teacher Experience } & -0.1792 & -0.1651 & -0.2250 \\
\hline & $(0.32)$ & $(0.29)$ & $(0.31)$ \\
\hline \multirow[t]{2}{*}{ Const. } & $46.4887^{* * *}$ & $58.5119^{* * *}$ & $60.1416^{* * *}$ \\
\hline & (13.57) & (10.99) & (12.07) \\
\hline R squared & 0.64 & 0.71 & 0.68 \\
\hline Observations & 605 & 605 & 605 \\
\hline
\end{tabular}

To deal with a possible endogenity issue where public education excess levy revenue is potentially a choice variable, correlated with unobservables, such as the percent of the population 65 years of age of older, I instrument using a two-stage model. The instrumental variable (IV) regression analysis on all 55 West Virginia school districts from 1992 to 2002 shows that when instrumenting for the percentage of the population 65 years old and older, the amount of real revenue received from excess levies per pupil is shown to have a positive and significant influence on student achievement at all grade levels (Table 3.6). If the amount of real excess levy revenue increased by $\$ 1,000$ per pupil, then regression results suggest that the mean standardized 
test score increased by 0.71 to 1.00 . This indicates that an increase, while being a significantly large increase, can increase the percent of students performing above satisfactory within the school district. Past performance in the school district was shown to also have a positive influence on student achievement in all four grade levels. The level of poverty was shown, once again, to have a negative influence on performance in the $9^{\text {th }}$ and $11^{\text {th }}$ grades.

\begin{tabular}{|c|c|c|c|c|}
\hline \multicolumn{5}{|c|}{ Table 3.6: } \\
\hline \multirow{2}{*}{\multicolumn{5}{|c|}{$\begin{array}{c}\text { Determinants of Student Achievement in West Virginia: 1992-2002 } \\
\text { Instrumental Variable (IV) Regression Model }\end{array}$}} \\
\hline & & & & \\
\hline \multicolumn{5}{|c|}{ Full Dataset } \\
\hline \multicolumn{5}{|c|}{ (Dependant Variable: Grade-Level Mean Standarized Score) } \\
\hline & Grade 3 & Grade 6 & Grade 9 & Grade 11 \\
\hline \multirow[t]{2}{*}{ Real excess levy revenues per student $(\$ 1,000)$} & $0.7125^{*}$ & $0.9965^{\star}$ & $0.7852^{*}$ & $0.8621^{*}$ \\
\hline & $(0.44)$ & $(0.64)$ & $(0.49)$ & $(0.53)$ \\
\hline \multirow[t]{2}{*}{ All other real revenues per student $(\$ 1,000)$} & 0.0631 & 0.0763 & 0.0247 & 0.0389 \\
\hline & $(0.05)$ & $(0.07)$ & $(0.05)$ & $(0.06)$ \\
\hline \multirow[t]{2}{*}{$\%$ Retained } & -0.0030 & -0.0026 & - & - \\
\hline & $(0.02)$ & $(0.04)$ & - & - \\
\hline \multirow[t]{2}{*}{$\%$ Poverity } & 0.0046 & -0.0632 & $-0.2174^{* * *}$ & $-0.2087^{\star \star *}$ \\
\hline & $(0.05)$ & $(0.07)$ & $(0.06)$ & $(0.06)$ \\
\hline \multirow[t]{2}{*}{ Past School District Performance (lagged 2 yrs) } & $0.2784^{* * *}$ & $0.3049^{\star * *}$ & $0.3536^{\star \star *}$ & $0.3392^{* \star *}$ \\
\hline & $(0.06)$ & $(0.05)$ & $(0.05)$ & $(0.05)$ \\
\hline \multirow[t]{2}{*}{ Per Capita Personal Income } & -0.0423 & 0.1901 & -0.2503 & 0.1968 \\
\hline & $(0.19)$ & $(0.22)$ & $(0.18)$ & $(0.18)$ \\
\hline \multirow[t]{2}{*}{ Student density } & $-0.9603^{*}$ & 1.1687 & 0.7230 & $1.9593^{* *}$ \\
\hline & $(0.55)$ & $(0.95)$ & $(0.64)$ & $(0.89)$ \\
\hline \multirow[t]{2}{*}{ Pupil/teacher ratio } & 0.4840 & -0.8373 & 0.2807 & -0.9607 \\
\hline & $(0.61)$ & $(0.96)$ & $(0.72)$ & $(0.73)$ \\
\hline \multirow[t]{2}{*}{ Average Teacher Experience } & 0.0995 & 0.0854 & 0.1333 & 0.1978 \\
\hline & $(0.22)$ & $(0.33)$ & $(0.27)$ & $(0.25)$ \\
\hline \multirow[t]{2}{*}{ Const. } & $32.5781^{* * *}$ & $48.9307^{\star * *}$ & $42.2139^{\star * *}$ & $54.2252^{* * *}$ \\
\hline & (7.19) & $(14.37)$ & $(11.77)$ & $(11.87)$ \\
\hline R squared & 0.73 & 0.72 & 0.72 & 0.72 \\
\hline Observations & 605 & 605 & 605 & 605 \\
\hline
\end{tabular}

\subsection{Conclusion}

Since the ground breaking research by Coleman in 1996, the relationship between student achievement or performance and school resources has been widely analyzed. Some research has deemphasized the importance of school inputs and focused on the impacts families and peers 
have on achievement. Others have shown that school resources must be categorized and looked at individually to see if there is an impact. This report looked at a particular school resource, excess public education levies, and its influence on third, sixth, ninth and eleventh grade student achievement in West Virginia from 1992 to 2002.

Excess school levies in West Virginia are pushed by politicians, boards of educations, teachers, and parents. Each vowing that without these additional property tax revenues for public education, their school system will not adequately educate their students. Many have been convinced that without the passage of these additional levies students in their school district will fall behind and not be able to compete academically amidst their peers throughout the state and nation. Analysis indicates that instructional or classroom resources from excess levies can have a positive impact on student achievement in all grade levels in school districts that are not reliant on these additional funds. School districts that continuously have excess levies for public education are shown to have high levels of academic performance, especially compared with districts that never collect these additional funds, but an increase of these funds is shown to not significantly influence academic performance. This result supports the theory that school districts that continuously adopt excess levies are reliant on those funds and treat them as typical funds for educational purposes.

Characteristics, such as population make-up and income levels, are shown to possibly affect the probability a school district votes for an excess levy in West Virginia. School districts with aging populations, declining population levels, and populations becoming more impoverished are shown to decrease the likelihood that an excess levy will be adopted. Higher levels of student performance, which are typically found in school districts that adopt an excess levy, are shown to increase the probability an excess levy for public education will be approved. 
Other variables were also found to influence the level of academic performance. Past performance of students in the same grade and school district, which can be used to estimate the effect of achievement expectations and quality levels of school district resources, are shown to positively influence academic achievement in all grade levels. The level of childhood poverty in school districts was shown to negatively affect student performance especially at the highest grade levels in West Virginia.

These results suggest that an influx of unexpected classroom or instructional resources can promote a possible positive increase in academic achievement. The next step in this research is to explore if additional revenues from public education excess levies in another state, such as Washington, influences achievement. By using another state, which may authorize boards of education to establish public education excess levies at a different rate (i.e. less than every 5 years), reliance on additional instructional funds in the form of public education excess levies can be further explored. 


\section{Chapter 4: Boys Are Better At Math? An Examination of the Effects of Gender on Student Achievement}

\subsection{Introduction}

A wide range of theories have been explored to explain differences in student achievement. One theory to explain varying performance levels involves gender. Economists have found gender gaps in mathematics and reading performance with the most statistically significant gap found in mathematics. This gap, which typically favors boys, has been theoretically explained by biological differences, societal factors, and abilities on standardized tests.

There is a gender gap in mathematics in West Virginia but not like the one typically found in the literature and research. Academic performance on standardized tests in mathematics for $5^{\text {th }}$ graders in West Virginia shows that girls tend to achieve at higher levels than boys. From 2003 to 2007 , girls performed on average $6.8 \%$ higher on mathematics standardized tests than boys. The goal of this chapter is to explore the gender gap in mathematics in West Virginia from 2003 to 2007 . This chapter will continue to delve into the influence of other factors that may affect achievement, such as resources, peers, school district characteristics and family, while concentrating on the effects of gender. Analysis will explore if different factors affect genders differently in terms of mathematical performance.

The next sections of this chapter will look at the literature on the influences on academic achievement, explore the data on West Virginia $5^{\text {th }}$ graders from 2003 to 2007, and analyze the effects, if any, on student achievement. Finally, it will determine if the effects of certain factors effect boys' and girls' mathematical achievement at different levels and what may be the cause of the gap in performance in West Virginia $5^{\text {th }}$ graders. 


\subsection{Gender Gap in Mathematics}

Numerous economic studies have examined the relationship between gender and academic achievement. Globally, gender gaps have been found in student performance in reading and mathematics. Marks (2008) examined student performance of 15 year olds in OECD’s 2000 Programme from International Student Assessment (PISA) project and found that in most countries, girls on average received 32 more score points than boys in reading while the gender gap was 11 score points in the opposite direction for math. Else-Quest, Hyde, and Linn (2010) showed, using the same dataset as Marks but from 2003, that the gender gap in math occurs in some countries but not in all of them. They conclude that the geographical differences in the gender gap in mathematics may be due to cultural variations in opportunity structures across countries.

In the United States, the gender gap in mathematics has also been examined with similar results. Fryer and Levitt (2010) used the Early Childhood Longitudinal Study Kindergarten Cohort (ECLS-K), which included 20,000 kids entering kindergarten in 1998 to show the gender gap in mathematics. Using Equation [4.1], Fryer and Levitt concluded that the mathematics performance levels of girls and boys were equivalent when they entered kindergarten; however, by the end of fifth grade, the girls' performance had fallen 0.2 standard deviations below the performance level of the boys. This gap, however, could not be explained by varying investment levels, parental expectations or biased tests. Fryer and Levitt did, however, find geographic differences in the size of the gap in mathematics. They concluded that the gap was the largest in New England and the smallest in the southern part of the United States.

$$
\text { Score }_{i}=\alpha+\gamma \text { Gender }_{i}+x_{i} \beta+\varepsilon_{i}
$$


Additional research on the gender gap in the United States also found geographic differences in the size of the gap in mathematics. Using individual level $8^{\text {th }}$ grade standardized test score data from the National Assessment of Educational Progress, Pope and Sydnor (2010) found that states with large gender gaps in mathematics tended to have the opposite gender gap in reading. Using these test scores of high achieving ${ }^{23} 8^{\text {th }}$ graders in 2000, 2003, and 2005, Pope and Sydnor calculated a stereotype adherence index which was an average of a state's malefemale ratio in math and the state's male-female ratio in reading for the top 5 percent of students. Those states with a high stereotype adherence index were characterized as having large gender gaps and were found predominately in the South and Mountain West. In this study, West Virginia's high performing $8^{\text {th }}$ graders showed to have a high index and thus a large gender disparity in mathematics favoring boys.

The results of the analysis of high achieving $8^{\text {th }}$ graders do not coincide with the results Fryer and Levitt found of the gap in $5^{\text {th }}$ grades throughout the United States. These two studies indicate that the gap in mathematics in the South is the smallest in $5^{\text {th }}$ graders but gender disparity is the highest in the South among high achieving $8^{\text {th }}$ graders. This chapter will explore one state in the South, West Virginia, where the gender gap is found to be the opposite for $5^{\text {th }}$ graders by combining gender with educational production function analysis used to explore the factors that influence student achievement.

West Virginia is not the only state where economists and educational researchers have found that the mathematical gender gap is reversed. Brandon, Newton, and Hammond (1987) found, using analysis of Stanford Achievement Tests in 1982-84 for grades 4, 6, 8, and 10, that girls outperform boys in mathematics in Hawaii. This research also found that high performing

\footnotetext{
${ }^{23}$ Pope and Sydnor defined high achieving as students whose test scores were in the top 25 percent and top 5 percent.
} 
girls out achieved high performing boys in mathematics and the gender difference increased as the grade level increased in Hawaii.

Before analysis on West Virginia $5^{\text {th }}$ graders is completed one must explore why gender gaps persist in mathematics. Economists and other researchers have hypothesized that many factors such as culture, biased teaching efforts, and parental input are reasons for the gender gap in mathematics. However, little empirical evidence can back up these theories concluding that gender differences in learning mathematics are complex. The one theory to explain the mathematical gender gap that has supporting empirical results involves the level of cognitive ability measured. Early research on the gender gap in mathematics summarized by Fennema (1974), indicates that boys outperform girls in high-level cognitive tasks while girls were found to excel at low-level cognitive tasks. New research shows that mathematics test scores by both genders are influenced by cognitive as well as non-cognitive abilities (i.e. response to competitive environment). Niederle and Yesterlund (2010) summarize gender research finding that competition rather than innate skills cause or magnify gender differences in test scores.

\subsection{Data}

To research the relationships between student achievement and gender, data was collected for West Virginia $5^{\text {th }}$ graders from 2003 to 2007 . Academic achievement was measured by proficiency levels in mathematics on the state's standardized test ${ }^{24}$ for all fifty-five school districts. The level of proficiency in mathematics was determined by the number of students scoring at or above the mastery level in the subject, which requires a demonstration of knowledge, comprehension, and application of skills.

\footnotetext{
${ }^{24}$ West Virginia's standardized test for this time period was the WESTEST, which was developed in 2003 and remained as the state's academic assessment tool till 2008. All students in grades 3 through 10 were required to take the WESTEST. Results of the test are not comparable to any other state.
} 
Figure 4.1 shows the mathematical proficiency levels of $5^{\text {th }}$ graders in West Virginia from 2003 to 2007 . On average, $5^{\text {th }}$ graders scored between 70.2 percent and 76.5 percent proficiency during this time with the lowest level of proficiency occurring at the first year this standardized test was used. As previously mentioned, $5^{\text {th }}$ grade girls achieved proficiency levels in mathematics that were, on average, 6.8 percent above the proficiency levels of their male counterparts. The largest gender gap in mathematics proficiency during this time period occurred in 2007 when girls' proficiency levels equaled 76.6 percent while only 70.9 percent of boys were found to be proficient.

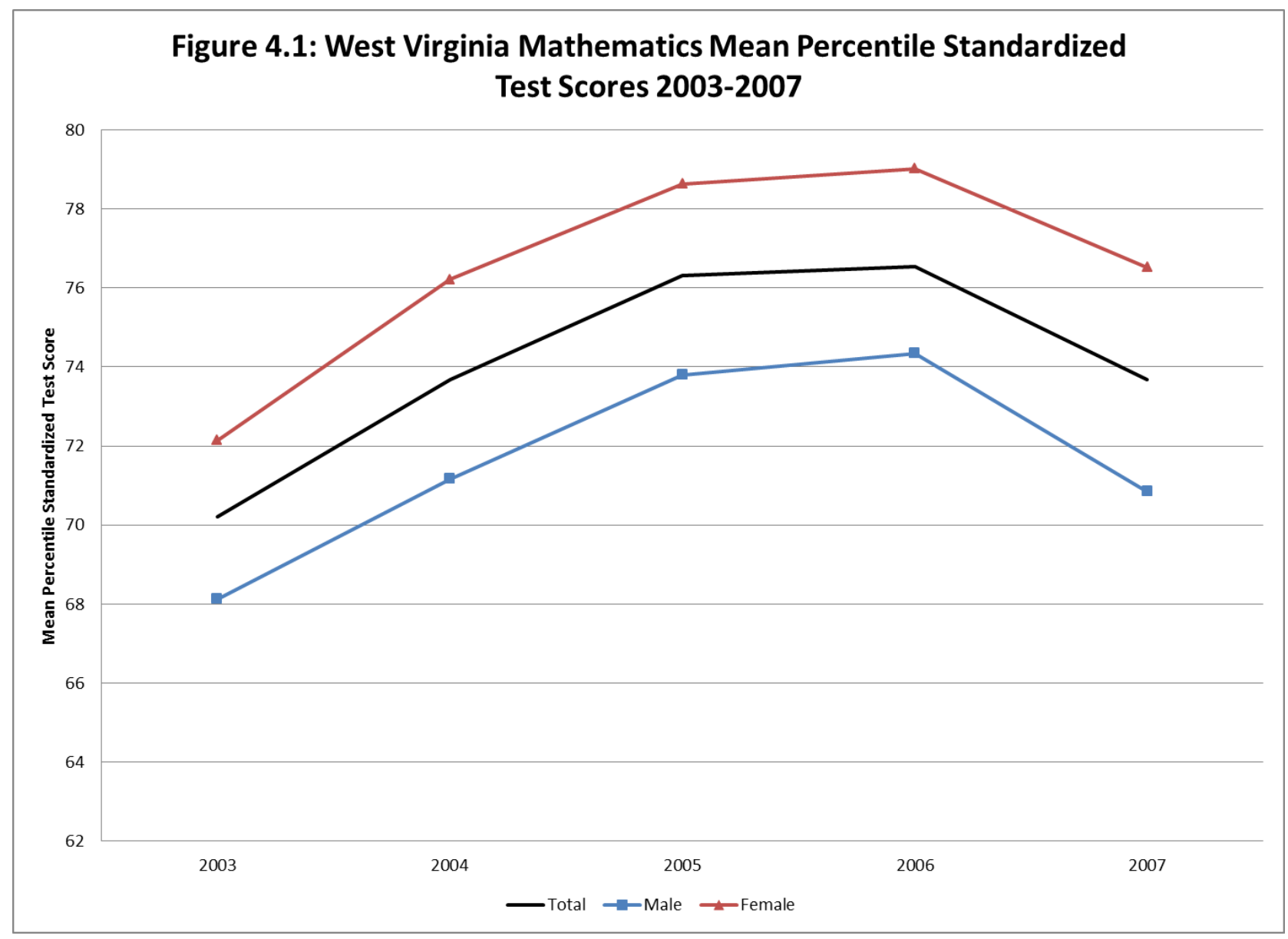

One might believe that this gender gap in mathematics which favors girls instead of boys may be due to the distribution of gender in $5^{\text {th }}$ grade. That theory, however, can be ruled out. 
From 2003 to 2007, girls accounted for 48.5 percent of the student population in $5^{\text {th }}$ grade in West Virginia leaving a equalized distribution of students in terms of gender. During this time period the largest enrollment difference occurred in 2004 when boys accounted for an estimated $52.1 \%$ of total net enrollment.

The district-level $5^{\text {th }}$ grade data will also consider the effects of family, peer, and school district inputs as used in educational production function literature. For family inputs, family resources were estimated using the percentage of $5^{\text {th }}$ graders eligible for free or reduced price meals through the National School Lunch Program. This input measures the level of students from households that are characterized as having low levels of income. From 2003 to 2007, approximately 56.4 percent of $5^{\text {th }}$ graders were eligible for the free or reduced lunch program in West Virginia (Table 4.1).

Peers have been found to have substantial impacts on academic performance (Hanushek et al 2003). Peer performance, in terms of poor academic achievement, has been found to have an effect on a student's overall performance. To account for this relationship, the percentage of students that were retained or held back due to low levels of academic performance was used.

A variety of school district resource inputs were examined for this analysis. These inputs included real expenditures, pupil teacher ratios, and average teacher experience. Expenditures were collected per pupil and, to remain consistent throughout this dissertation, combined instructional and non-instructional inflation adjusted expenditures. Pupil-teacher ratios were calculated as the average full-time equivalent $5^{\text {th }}$ grade teacher per net enrollment of $5^{\text {th }}$ graders in each school district. From 2003 to 2007, pupil-teacher ratios for $5^{\text {th }}$ graders averaged 14.86 students per teacher (Table 4.1). The average teacher experience of all teachers in each school district was also used as a school resource. 
Other school district inputs incorporated in this analysis include past performance in each grade in each school district, personal income per capita, and student density levels by school district. Mean standardized test scores lagged two years is included in the analysis to measure the academic expectations for each grade in each school district and the quality of teachers and classroom resources in each school district. Personal income per capita is a proxy for the overall income level of the school district. Student density levels represent the number of fifth graders enrolled in public school per square mile in the school district. During this time span, there were an estimated 1.04 fifth graders per square mile in West Virginia.

\begin{tabular}{|c|c|c|c|c|}
\hline \multicolumn{5}{|c|}{ Table 4.1: } \\
\hline \multirow{2}{*}{\multicolumn{5}{|c|}{$\begin{array}{l}\text { Summary Statistics } \\
\text { West Virginia School Districts Grade 5: 2003-2007 }\end{array}$}} \\
\hline & & & & \\
\hline \multicolumn{5}{|c|}{ Full Dataset of All 55 School Districts } \\
\hline School District Level Variable & Mean & Std. Dev. & Min & Max \\
\hline Net Enrollment in Grade 5 & 375.78 & 351.11 & 60.0 & $2,157.0$ \\
\hline$\%$ of Enrollment Male & 51.51 & 3.66 & 35.6 & 60.8 \\
\hline$\%$ of Enrollment Female & 48.49 & 3.66 & 39.2 & 64.5 \\
\hline Math Percentile Score & 74.09 & 6.60 & 57.0 & 90.0 \\
\hline Math Percentile Score Male & 71.66 & 7.06 & 53.0 & 90 \\
\hline Math Percentile Score Female & 76.51 & 6.84 & 58.0 & 92.0 \\
\hline Past School District Performance (lagged 2 yrs) & 72.12 & 9.11 & 45.0 & 90.0 \\
\hline Past School District Male Performance (lagged 2 yrs) & 72.00 & 9.04 & 45.0 & 90.0 \\
\hline Past School District Female Performance (lagged 2 yrs) & 77.19 & 9.67 & 55.0 & 92.0 \\
\hline Percent Retained & 1.21 & 5.55 & 0.0 & 8.9 \\
\hline Real Expenditure Per Student & $9,860.04$ & $3,508.81$ & $3,852.0$ & $47,611.4$ \\
\hline Percent Grade 5 Poverty & 56.40 & 10.52 & 28.9 & 88.9 \\
\hline Pupil Teacher Ratio & 14.86 & 0.85 & 12.6 & 17.0 \\
\hline Average Teacher Experience & 16.04 & 1.62 & 12.5 & 20.8 \\
\hline Personal Income Per Capita & $24,557.39$ & $4,293.47$ & $16,039.0$ & $39,429.0$ \\
\hline Grade 5 Student Density & 1.04 & 0.97 & 0.1 & 4.1 \\
\hline
\end{tabular}

\subsection{Methodology and Results}

To determine if gender has an effect on the academic achievement of $5^{\text {th }}$ graders in West Virginia from 2003 to 2007, analysis began using a basic OLS regression where:

MathProficiency $_{\text {it }}=\mathrm{f}\left(\right.$ Gender $_{\text {it }}$, Peers $_{i t}$, Family $_{\text {it }}$, SchoolDistResources $_{\text {it }}$, SchoolDist $\left._{\text {it }}\right)+\varepsilon_{\text {it }} \quad$ [4.2] 
where MathProficiency is the level of proficiency reached by each school district in $5^{\text {th }}$ grade in mathematics, Gender is the percentage of net enrollment accounted for by females, and $\varepsilon$ is the error term. The equation ties together the gender literature with the education production function literature explained in Chapter 2 and 3. It allows us to determine what aspects of resources, family, and school districts affect student achievement at the school district level as well as the impact of gender.

The first column of Table 4.2 shows the results of this basic OLS regression. For $5^{\text {th }}$ grade mathematic proficiency in West Virginia, the percentage of net enrollment per school district that was female was not found to be a significant influence. ${ }^{25}$ Factors that were found to affect mathematical proficiency levels included peers, school resources, family inputs, and density levels. Peer inputs, measured as retention rates, were found to significantly affect math achievement in a negative manner. Real expenditures per pupil, pupil-teacher ratio, and average teacher experience were found to have significantly positive effect on the total mathematical proficiency of $5^{\text {th }}$ graders from 2003 to 2007 in West Virginia. Lagged test scores, which for this analysis measures the expectations and quality level of the school district, was also found to positively influence West Virginia achievement in mathematics.

To analyze this panel dataset with interest in the impact of variables that vary over time and over school districts, a fixed effects model was used (Equation 4.3).

MathProficiency $_{i t}=f\left(\right.$ Gender $_{i t}$, Peers $_{i t}$, Family $_{i t}$, SchoolResources $_{i t}$, Location $\left._{i t}\right)+\tau_{i t}+\rho_{i t}+\varepsilon_{i t}[4.3]$ where $\tau$ is the time fixed effect and $\rho$ is the school district fixed effect.

Fixed effect analysis allows for time and school district variation, which may impact or bias the outcome variables, to be controlled in order to assess the net effect. Table 4.2 column 2 displays the results from the fixed effect regression analysis. In controlling for variables that do

\footnotetext{
${ }^{25}$ Similar results were found when the percentage of males was used in this same regression analysis framework.
} 
not change over time, peers and expenditures are shown to have a significant effect on mathematical performance while gender is still shown to not significantly affect proficiency levels. Past performance in the school district and retention rates are shown to have significant but opposite effects on mathematical achievement with lagged scores having a larger influence. This result follows the thought that students benefit more from high achieving schoolmates than average or low achieving peers. Real expenditures per student were shown to also influence mathematical achievement at a positive rate. In looking at the time and school district fixed effect result, an increase of $\$ 1,000$ of real expenditures per pupil in each school district would increase the level of total mathematical proficiency by 0.02 .

Table 4.2:

Determinants of Student Achievement in Grade 5 in West Virginia: 2003-2007 OLS and Time and School District Fixed-Effects Model Full Dataset

\begin{tabular}{|c|c|c|}
\hline \multicolumn{3}{|c|}{ (Dependant Variable: Grade 5 Math Mean Standarized Score) } \\
\hline & $(1)$ & $(2)$ \\
\hline & OLS & Fixed Effect \\
\hline \multirow[t]{2}{*}{$\%$ of Enrollment Female } & 0.0533 & 0.0499 \\
\hline & $(0.10)$ & $(0.07)$ \\
\hline \multirow[t]{2}{*}{ Peer Percentile Score } & $0.2811^{\star \star *}$ & $0.1664^{\star *}$ \\
\hline & $(0.05)$ & $(0.07)$ \\
\hline \multirow[t]{2}{*}{ Percent Retained (Grade 5) } & $-0.0855^{\star * *}$ & $-0.0364^{*}$ \\
\hline & $(0.03)$ & $(0.02)$ \\
\hline \multirow[t]{2}{*}{ Real expenditure Per Student $(\$ 1,000)$} & $0.0231^{\star *}$ & $0.0182^{*}$ \\
\hline & $(0.01)$ & $(0.01)$ \\
\hline \multirow[t]{2}{*}{ Percent Poverty (Grade 5) } & $-0.0848^{*}$ & -0.0097 \\
\hline & $(0.05)$ & $(0.05)$ \\
\hline \multirow[t]{2}{*}{ Pupil Teacher Ratio (Grade 5) } & $1.1079^{* \star}$ & 1.2008 \\
\hline & $(0.41)$ & $(0.81)$ \\
\hline \multirow[t]{2}{*}{ Average Teach Experience } & $0.4481^{*}$ & 0.7023 \\
\hline & $(0.25)$ & $(0.78)$ \\
\hline \multirow[t]{2}{*}{ Personal Income Per Capita $(\$ 1,000)$} & -0.0094 & -0.0291 \\
\hline & $(0.01)$ & $(0.05)$ \\
\hline \multirow[t]{2}{*}{ Grade 5 Student Density } & $0.9671^{* *}$ & 0.6990 \\
\hline & $(0.34)$ & $(1.82)$ \\
\hline R-Squared & 0.36 & 0.80 \\
\hline Observations & 275 & 275 \\
\hline
\end{tabular}


The results presented in Table 4.2 shows that while $5^{\text {th }}$ grade girls perform better in mathematics, the percentage of girls in West Virginia school districts does not influence total mathematical achievement level in the school district. This result is consistent with the breakdown of net enrollment. The percentage of girls in the $5^{\text {th }}$ grade in West Virginia school districts between 2003 and 2007 is not statistically different from the percentage of boys and thus has no influence on achievement.

While gender does not seem to affect the mathematical proficiency levels of $5^{\text {th }}$ graders in West Virginia at the school district level, the question of what effects boys' academic achievement versus girls' academic achievement in math still persists. To answer that question, achievement for all $5^{\text {th }}$ grade West Virginia students from 2003 to 2007 was examined along with achievement for girls only and boys only using Equation 4.3 and a time and school district fixed effects model. ${ }^{26}$

In examining the inputs that affect mathematical proficiency for all $5^{\text {th }}$ graders at the school district level in West Virginia from 2003 to 2007 (Table 4.3), peers and school resources continue to have an impact on achievement. The past academic performance in the school district on standardized test scores in mathematics has a significant and positive impact on achievement. The percentage of classmates that are held back was shown to have a negative impact on math proficiency levels of $5^{\text {th }}$ graders. Real expenditures per student were also found to have significant and positive impact on mathematical achievement which follows the results found in Table 4.2 and previous chapters.

In terms of the mathematical proficiency of girls and boys in $5^{\text {th }}$ grade in West Virginia during this time period, past academic performance was shown to influence their level of

\footnotetext{
${ }^{26}$ Chow test was performed to test whether the coefficients estimated for boys' mathematical proficiency was equal to girls' mathematical proficiency. Test indicated that the coefficients for the genders were statistically different.
} 
achievement. Poorly performing peers, measured by the percentage of children held back or retained, were shown to only affect the mathematical performance of boys. One could conclude that this may be due to the fact that a higher percentage of the students that are retained are boys but without the appropriate data that conclusion cannot be verified. Classroom size, measured by the number of students per teacher, does not a have a significant influence on boys but it is shown to have an effect on girls. The mathematical proficiency levels of girls in $5^{\text {th }}$ grade in West Virginia is negatively affected by pupil-teacher ratios meaning that as the number of students per teacher increases the lower the level of mathematical proficiency is found in girls. This result indicates that girls perform at higher levels in smaller classrooms where more individual level attention from the teacher is possible.

\begin{tabular}{|c|c|c|c|}
\hline \multicolumn{4}{|c|}{ Table 4.3: } \\
\hline \multirow{2}{*}{\multicolumn{4}{|c|}{$\begin{array}{c}\text { Determinants of Student Achievement in Grade } 5 \text { in West Virginia: 2003-2007 } \\
\text { Time and School District Fixed-Effects Model }\end{array}$}} \\
\hline & & & \\
\hline \multicolumn{4}{|c|}{ Full Dataset, Males, and Females } \\
\hline \multicolumn{4}{|c|}{ (Dependant Variable: Grade 5 Math Mean Standarized Score for Males and Females, Males Only, or Females Only) } \\
\hline & $\begin{array}{l}\text { Males \& } \\
\text { Females }\end{array}$ & Males Only & Females Only \\
\hline \multirow[t]{2}{*}{ \% of Enrollment Female } & 0.0499 & 0.0429 & 0.0502 \\
\hline & $(0.07)$ & $(0.08)$ & $(0.08)$ \\
\hline \multirow[t]{2}{*}{ Percent Retained (Grade 5) } & $-0.0364^{*}$ & $-0.0357^{*}$ & 0.0193 \\
\hline & $(0.02)$ & $(0.02)$ & $(0.03)$ \\
\hline \multirow[t]{2}{*}{ Real expenditure Per Student $(\$ 1,000)$} & $0.0182^{*}$ & 0.0613 & 0.0532 \\
\hline & $(0.01)$ & $(0.06)$ & $(0.04)$ \\
\hline \multirow[t]{2}{*}{ Percent Poverty (Grade 5) } & -0.0097 & -0.0172 & 0.0014 \\
\hline & $(0.05)$ & $(0.06)$ & $(0.07)$ \\
\hline \multirow[t]{2}{*}{ Past School District Performance (lagged 2 yrs) } & $0.1664^{* *}$ & $0.1882^{* *}$ & $0.1827^{\star * \star}$ \\
\hline & $(0.07)$ & $(0.07)$ & $(0.06)$ \\
\hline \multirow[t]{2}{*}{ Pupil Teacher Ratio (Grade 5) } & -1.2008 & -1.2316 & $-1.6756^{*}$ \\
\hline & $(0.81)$ & $(0.85)$ & $(0.91)$ \\
\hline \multirow[t]{2}{*}{ Average Teacher Experience } & 0.7023 & 1.3520 & 0.5404 \\
\hline & $(0.78)$ & $(0.87)$ & $(0.91)$ \\
\hline \multirow[t]{2}{*}{ Personal Income Per Capita $(\$ 1,000)$} & -0.0291 & -0.0097 & -0.0432 \\
\hline & $(0.05)$ & $(0.06)$ & $(0.06)$ \\
\hline \multirow[t]{2}{*}{ Grade 5 Student Density } & 0.6990 & 1.9937 & 1.8996 \\
\hline & $(1.82)$ & $(2.15)$ & $(1.84)$ \\
\hline R-Squared & 0.80 & 0.75 & 0.78 \\
\hline Observations & 275 & 275 & 275 \\
\hline
\end{tabular}


Results from Table 4.3 show that smaller class sizes increase the mathematical performance of females. School resources, in the form of real expenditures per pupil, were not, however, found to be a significant influence on female (or male) performance. A breakdown of these total real expenditures, however, shows a different story. Table 4.4 uses the time and school district fixed effect model in Equation 4.3 with total real expenditures broken down into two categories: instructional and non-instructional. Since smaller class sizes (i.e. smaller pupilteacher ratios) were found to influence female mathematical achievement one can hypothesize that increased expenditures, which are used for all classroom resources including teachers, would also have a significant effect on female achievement. This hypothesis is found to be true. Real instructional expenditures per pupil were found to have a small, positive, but significant impact on the mathematical proficiency levels of $5^{\text {th }}$ grade girls in West Virginia. Instructional or noninstructional expenditures were found to significantly affect the percentage of $5^{\text {th }}$ grade boys proficient in mathematics.. This result shows that females are affected by increased instructional expenditures that can result in more teachers and thus smaller class sizes. 
Table 4.4:

Determinants of Student Achievement in Grade 5 in West Virginia: 2003-2007

Time and School District Fixed-Effects Model

Full Dataset of Males Only and Females Only

(Dependant Variable: Grade 5 Math Mean Percentile Standarized Score for Males Only or Females Only)

0.0470

$(0.08)$

Percent Retained (Grade 5)

$-0.0247^{\star}$

$(0.01)$

0.2592

$(0.21)$

0.0043

Real Non-Instructional Expenditure Per Student $(\$ 1,000)$

$(0.02)$

Percent Poverty (Grade 5)

$-0.0169$

Females Only

0.0527

$(0.08)$

$-0.0186$

Real Instructional Expenditure Per Student $(\$ 1,000)$

$(0.06)$

Past School District Performance (lagged 2 yrs)

$0.1873^{\star \star}$

$(0.03)$

$0.0179^{*}$

$(0.01)$

0.0017

$(0.01)$

$-0.0027$

Pupil Teacher Ratio (Grade 5)

(0.07)

$(0.07)$

$-1.2911$

$0.1854^{\star \star \star}$

Average Teach Experience

(0.84)

$1.4900^{\star}$

(0.06)

Personal Income Per Capita $(\$ 1,000)$

(0.85)

$-0.0041$

(0.06)

Grade 5 Student Density

2.0577

(2.16)

R-Squared

0.75

Observations

275

$-1.7148^{\star}$

(0.90)

0.4920

(0.93)

$-0.0428$

(0.06)

1.8145

(1.85)

0.78

Note: Robust standard errors are shown in parentheses. Significance levels: ${ }^{\star \star \star}$ at $1 \%,{ }^{\star \star}$ at $5 \%$, and ${ }^{\star}$ at $10 \%$.

Another way to explore the influences of gender on mathematical student achievement of $5^{\text {th }}$ graders is to calculate the gender gap (i.e. average girl score minus average boy score) in each school district for each year and see if that gap has a significant influence of the mathematical performance of the school district as shown in Equation 4.4.

Gap $_{i t}=\mathrm{f}\left(\right.$ MathProficiency $_{\mathrm{it}}$, Peers $_{\mathrm{it}}$, Family $_{\mathrm{it}}$, SchoolDist $_{\mathrm{it}}$, Location $\left._{\mathrm{it}}\right)+\tau_{\mathrm{it}}+\rho_{\mathrm{it}}+\varepsilon_{\mathrm{it}}$

where Gap is equal to average female mathematics standardized test score in each school district for each year minus the average male mathematics score; peers, family, school resources, and location are the same as in previous equations; $\tau$ is the time fixed effect; $\rho$ is school district fixed effect, and $\varepsilon$ is the error term. Table 4.5 shows the results of using the time and school district fixed effects model in Equation 4.4 as well as the time and school district fixed effects model 
which calculates the gender gap as the ratio of girls proficiency levels to boys proficiency levels. The ratio of proficiency coincides with research by Pope and Sydnor (2010). Both models show that the percentage of females in each school district did not have a significant impact on the gender gap. This result corresponds with the results in Table 4.2 where gender did not affect school district mathematics proficiency. The only factor shown to significantly influence the gender gap in mathematics is density. As the number of students per square mile increases, the gap measured by female proficiency minus male proficiency or the ratio of female proficiency and male proficiency declines.

Table 4.5:

Determinants of Student Achievement in Grade 5 in West Virginia: 2003-2007 Time and School District Fixed-Effects Model Full Dataset with Males and Females (Dependant Variable: Grade 5 Math Gender Gap)

\begin{tabular}{|l|c|c|}
\hline & $\begin{array}{c}\text { Gap = female - } \\
\text { male }\end{array}$ & $\begin{array}{c}\text { Gap }= \\
\text { female/male }\end{array}$ \\
\hline \% of Enrollment Female & 0.0205 & 0.0449 \\
\hline Percent Retained (Grade 5) & $(0.09)$ & $(0.15)$ \\
\hline Real Instructional Expenditure Per Student $(\$ 1,000)$ & -0.0185 & -0.0293 \\
\hline & $(0.03)$ & $(0.06)$ \\
\hline Real Non-Instructional Expenditure Per Student $(\$ 1,000)$ & 0.2874 & 0.0049 \\
\hline Percent Poverty (Grade 5) & $(0.20)$ & $(0.03)$ \\
\hline & 0.0129 & 0.0018 \\
\hline Past School District Performance (lagged 2 yrs) & $(0.01)$ & $(0.04)$ \\
\hline & -0.0435 & 0.0562 \\
\hline Pupil Teacher Ratio (Grade 5) & $(0.07)$ & $(0.11)$ \\
\hline & 0.0941 & 0.1246 \\
\hline Average Teach Experience & $(0.08)$ & $(0.12)$ \\
\hline Personal Income Per Capita $(\$ 1,000)$ & 0.4655 & -0.6393 \\
\hline Grade 5 Student Density & $(0.78)$ & $(1.20)$ \\
\hline & 0.9229 & 0.0161 \\
\hline R-Squared & $(0.98)$ & $(0.02)$ \\
\hline Observations & 0.0310 & 0.0042 \\
\hline Note: Robust standard errors are shown in parentheses. Significance levels: $: * *$ at $1 \%{ }^{*}{ }^{* *}$ at $5 \%$, and * at $10 \%$. \\
\hline
\end{tabular}




\subsection{Reasons behind Gap in $5^{\text {th }}$ Grade Mathematics in West Virginia}

From 2003 to 2007, school district proficiency levels in West Virginia for $5^{\text {th }}$ graders showed that girls outperformed boys. This result is not consistent with a majority of the economic literature and research on the gender gap in mathematics. Regression analysis in this chapter indicated that while girls had higher proficiency levels, the gender did not significantly influence the school districts proficiency levels in the subject and was not shown to significantly influence the gap in proficiency levels. One theory, as mentioned previously, that might help to explain the gap in mathematical proficiency levels in West Virginia $5^{\text {th }}$ graders involves the cognitive ability being tested by the standardized test and the environment in which the test was administered. Fennema (1974) concluded that the gap in the performance in mathematics favors one gender over the other depending on what type of cognitive ability the test to assess achievement is measuring. Niederle and Yesterlund (2010) added to this conclusion by showing that not only the type of cognitive ability being tested influences the gap in mathematics but the environment in which the test is being taken influences the gap and which gender it favors. To explore if the standardized test for West Virginia $5^{\text {th }}$ graders from 2003 to 2007 could have influenced the gender gap found in the mathematical proficiency levels, one would need to compare the results with another area taking the same test. Unfortunately, the standardized test used in the analysis of West Virginia $5^{\text {th }}$ graders from 2003 to 2007 was developed for only West Virginia to be a statewide accountability assessment tool thus it was not used in any other state.

Another way to explore if the standardized test used in West Virginia measured the abilities or was taken in an environment that would result in higher proficiency levels for girls, would be to compare the results of this standardized test with the performance levels of the same students on a different standardized test. In $5^{\text {th }}$ grade, West Virginia students from 2003 to 2007 
were tested using only one standardized test. ${ }^{27}$ Thus in order to evaluate the standardized test used in this chapter, I compare the results from $5^{\text {th }}$ graders in 2003 to 2007 with mathematic proficiency levels of West Virginia $5^{\text {th }}$ graders from 2010 to 2011 . By making this comparison, I am exploring the achievement levels of boys and girls in West Virginia in the $5^{\text {th }}$ grade with one group taking the standardized test analyzed throughout this chapter and another group of $5^{\text {th }}$ graders taking a different standardized test while assuming all other input factors for achievement are constant. Figure 4.2 shows that the gender gap in mathematics in $5^{\text {th }}$ grade does not exist in 2010 and 2011 when the state used a different standardized test as their assessment tool. This comparison hints that the standardized test used to assess the achievement levels of West Virginia $5^{\text {th }}$ graders may have been more conducive to the success of girls instead of boys.

\footnotetext{
${ }^{27}$ Note: results of a nationwide standardized test (i.e. National Assessment of Educational Progress) for $4^{\text {th }}$ graders in West Virginia during this time period (2003 and 2005) shows evidence that boys had higher achievement in mathematics than girls at the school district level.
} 


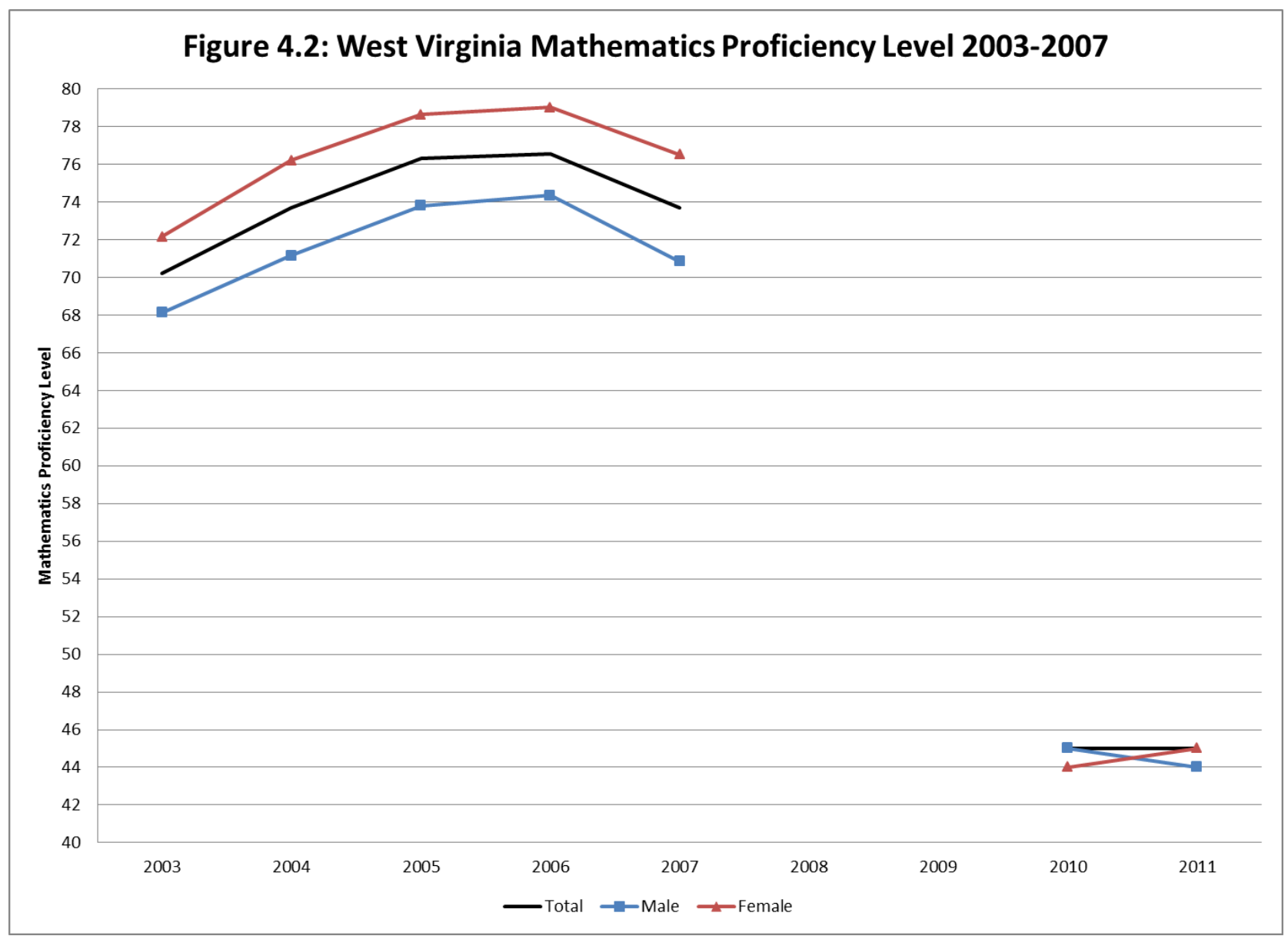

\subsection{Conclusion}

The long going argument about who is smarter: boys or girls remains. In examining the difference in academic achievement in mathematics, research has concluded that from country to country and state to state in the United States, a gender gap in favor of boys persists. However, in West Virginia, that conclusion cannot always be made. For $5^{\text {th }}$ graders, the mathematical proficiency levels for girls were found to be 6.8 percent higher than proficiency levels of boys from 2003 to 2007. Analysis of this district level data found that while girls performed better in mathematics, the percentage of girls in each school district may not have affected the overall proficiency levels of the school district. This result may be contributed to the percentage of girls 
enrolled in the $5^{\text {th }}$ grade during this time span was not significantly different than the percentage of boys and the level of proficiency of girls in relation to boys was not high enough to influence the total proficiency level of the school district. This result also indicates that the gap in mathematical performance exists but gender may not be the only reason for it. The skills tested and the environment in which the test was taken may have attributed to the gap in performance in mathematics for $5^{\text {th }}$ graders in West Virginia from 2003 to 2007.

In terms of what affects mathematical achievement for boys and if it is different for girls, I find that difference. Boys are significantly found to be influenced negatively by low performing peers. Girls, on the other hand, are influenced by classroom size. The higher the number of students per teacher (or larger the class) the lower the level of proficiency in mathematics girls tend to have. This result indicates that girls perform at higher levels when a higher level of individual attention is paid to the students. Females were also found to be significantly influenced by instructional expenditures. These expenditures, which were found to not affect mathematical proficiency levels in boys, go towards classroom supplies which include teachers. This coincides with the positive influence of small class sizes on female performance.

The next step in this research is to explore other grade levels in West Virginia during this same time period to see if girls had higher proficiency levels than boys in mathematics in all grades. Also, research into the gap in reading performance must also be completed to get a full account of the gender gap in achievement in West Virginia from 2003 to 2007. 


\section{Chapter 5: Conclusion}

Finding the factors that can not only affect student achievement but increase the level of achievement is important to researchers, parents, and policy makers throughout the United States and the world. Chapters 2 and 3 expand on the research exploring the effects of changing the level of school resources on student achievement in the public education system. Chapter 4 explores the relationship between gender and the achievement of students in mathematics and how the genders are affected differently by factors inside and outside the classroom.

The effects of school resource changes are important, especially to those lobbying for increased public education spending. Chapter 2 explored a major change to not only the way public education expenditures were allocated but to the basis from which revenue was collected. West Virginia, like a majority of the states in the United States, completed major overhauls to their public education funding system to comply with court rulings which required equality in public education resources. This change in West Virginia started in 1990 when the way property taxes (i.e. public education funding source) were collected and the formula for which public education resources were to be allocated from the state to the school districts was put into place. Analysis of the effect of these public education funding changes on student achievement in grades $3,6,9$, and 11 indicates that only a few grade levels were affected overall in the state but all grades in the areas that were characterized as low pre-policy spending districts were significantly impacted by the change in resources. While these effects were calculated to be based on changes in real expenditures above those typically found in West Virginia during this time period, there was clear evidence of their existence. The argument that growth in inputs, such as school resources, leads to growth in outputs or student achievement was also reinforced in the analysis of all 55 school districts in the state. The analysis of the change in public education 
funding in West Virginia in 1990 suggests that there may be important differences in the effects of spending on student achievement by sub-group.

Chapter 3 continues to explore the effects of a change in public education funding on student achievement in four grade levels in West Virginia. This chapter, however, examines public education funding changes that occur at the school district level instead of at the state level like in Chapter 2. The public education funding change at the school district level explored in this chapter are excess levies, revenue from which goes to classroom resources including technology, books, and teachers. These levies are voted on by the residents of each school district every 5 years. From 1992 to 2002, 39 of West Virginia's 55 school districts continuously had a public education excess levy in place. Analysis of the factors that increase (or decrease) the likelihood a school district would adopt an excess levy for public education showed that areas characterized as rural (measured by the number of students per square mile), having an increasing percentage of its population in retirement age, or an increase in the percentage of children living in impoverished households may decrease the probability the school district in West Virginia will vote in favor of an excess levy. In the school districts that continuously adopted an excess levy, those additional revenues were found to not significantly affect overall student achievement which indicates that these districts tend to be reliant on those monies and use them for the same instructional resources each year. In school districts not reliant on these additional funds, excess levies has a positive but small impact on student achievement in all four grade levels.

Chapters 2 and 3 explored the effects of public education funding on achievement but also explored other factors that are found to influence the level of academic performance. 
Common factors that were found to affect overall achievement in grades 3, 6, 9, and 11 include peer performance, level of childhood poverty, and level of urbanization.

These factors, including school resources, are important to achievement in West Virginia and thus were combined with gender to explore mathematics performance of $5^{\text {th }}$ graders in the state. Female students in West Virginia were found to outperform their male counterparts in $5^{\text {th }}$ grade mathematics proficiency which was an opposite result than found through most of the rest of the country and the world. School district level analysis of $5^{\text {th }}$ grade mathematical proficiency showed that while females had proficiency levels on average 6.8 percent above males, gender did not have a significant effect on mathematical performance for the entire school district. This result may be due to the percentage of girls enrolled in the $5^{\text {th }}$ grade during this time span was not significantly different than the percentage of boys.

Chapter 4 also explored what factors affect mathematical performance of females and if those same factors affect male performance in the same manner. Boys and girls were found to both be positively impacted by high performing peers. The mathematical proficiency level of girls; however, was found to be increased when the classroom size declined while boys' proficiency declined as the percent of students held back increased.

The analysis shown in Chapters 2, 3, and 4 gives insight in the factors that influence student achievement in West Virginia. While these results reflect the public education environment found in one state, they can be useful in other areas. Results indicate that increased school expenditures are most affective in areas that have low levels of resources. Additional instructional resources are hard to be approved in rural, aging, and impoverished areas but can be shown to be affective in districts not reliant on those additional funds. Male and female academic 
achievement is influenced in different manners and those factors can be adjusted in order to improve overall achievement.

The next step in this analysis is to apply these methodologies to other states. As previously mentioned, many states transformed their public education funding system around the same time period as West Virginia. Thus it is only natural to examine how student achievement changed in other areas of the country. Public educational excess levies are not found in many other states in the United States but for those states, such as Washington, the methodologies used to examine the effects of additional revenues on student achievement in West Virginia can be applied. Gender is and has been a hot topic in the education research area. Looking at other states and even other grades in West Virginia would be the logical next step and helpful to fully understand the causes for such gender gaps. 


\section{References}

Archibald, Sarah. 2006. Narrowing in on Educational Resources That Do Affect Student Achievement. Peabody Journal of Education. 84(4):23-42.

Bradley, Robert H, Renate Houts, Phillip R Nader, Marion O'Brien, Jay Belsky, and Robert Crosnoe. 2007. Adiposity and internalizing problems: Infancy to middle childhood. In Childhood and Adolescence: Volume 2 Understanding Development and Prevention. Ed. Hiram Fitzgerald and Vasiliki Mousouli, 73-92. Westport, CT: Praeger Publishers.

Brandon, Paul R, Barbara J Newton, and Ormond W Hammond. 1987. Children's Mathematics Achievement in Hawaii: Sex Differences Favoring Girls. American Education Research Journal. 24(3):437-461.

Card, David and Alan Krueger. 1996. School Resources and Student Outcomes: An Overview of the Literature and New Evidence from North and South Carolina. Journal of Economic Perspectives 10(4):31-50.

Card, David and Abigail Payne. 2002. School Finance Reform, the Distribution of School Spending, and the Distribution of Student Test Scores. Journal of Public Economics. 83: 49-82.

Chetty, Raj, John N Friedman, Nathaniel Hilger, Emmanuel Saez, Diane Whitmore Schanzenbach, and Danny Yagen. 2011. How Does Your Kindergarten Classroom Affect Your Earnings? Evidence From Project STAR. Quarterly Journal of Economics. CXXVI(4):15931660.

Coleman, James.1966. Equality of Educational Opportunity. U.S. Department of Health, Education, and Welfare, Office of Education.

Coleman, James S, Ernest Q Campbell, Carol J Hobson, James McPartland, Alexandar M Mood, Frederic D Weinfeld, and Robert L York. 1996. Equality of Educational Opportunity. Washington DC: US Government Printing Office.

Datar, Ashlesha and R Strum. 2006. Childhood overweight and elementary school outcomes. International Journal of Obesity. 30:1449-60.

Dilger, Robert Jay. Public School Finance in West Virginia. The West Virginia Public Affairs Reporter. 16(3):2-7.

Downes, TA and DN Fighio. 1997. School Finance Reform, Tax Limits and Student Performance: Do Reforms Level-Up or Dumb Down. Institute for Research on Poverty Discussion Paper No. 1142-97.

Duncombe, William and John Yinger. 2005. How Much More Does a Disadvantaged Student Cost? Economics of Education Review. 42:513-168. 
Else-Quest, Nicole M and Janet Shibley Hyde. 2010. Cross-National Patterns of Gender Differences in Mathematics: A Meta-Analysis. Psychological Bulletin. 136 (1):103-127.

Extracts from the Recht Decision of May 1982. West Virginia Archives \& History. <http://www.wvculture.org/history/education/recht01.html>

Fennema, Elizabeth. 1974. Mathematics Learning and the Sexes: A Review. Journal of Research in Mathematics Education. 5(3):126-39.

Finn, Jeremy D and Charles M Archilles. 1990. Answers and Questions about Class Size: A Statewide Experiment. American Educational Research XXVIII: 557-577.

Fryer, Roland G and Steven D Levitt. 2010. An Empirical Analysis of the Gender Gap in Mathematics. American Economic Journal: Applied Economics 2: 210-240.

Gable, Sara, Jennifer L Krull, and Yiting Chang. 2009. Implications of Overweight Onset and Persistence for Social and Behavioral Development Between Kindergarten Entry and Third Grade. Applied Developmental Science. 13:88-103.

Greenwald, Rob, Larry V Hedges, and Richard D Laine. 1996. The Effect of School Resources on Student Achievement. Review of Educational Research 66(3):361-96.

Gurley-Calvez, Tami and Amy Higginbotham. 2010. Childhood Obesity, Academic Achievement, and School Expenditures. Public Finance Review 38(5):619-646.

Hanushek, Eric. 1986. The Economics of Schooling: Production and Efficiency in Public Schools. Journal of Economic Literature. XXIV: 1141-1177.

Hanushek, Eric. 1996. Measuring Investment in Education. Journal of Economic Perspectives 10(4): 9-30.

Hanushek, Eric. 2006. Chapter 14: School Resources. Handbook of the Economics of Education, Volume 2. Ed. Eric Hanushek and Finish Welch.

Hanushek, Eric, John F Kain, Jacob M Markman, and Steven G Rivkin. 2003. Does Peer Ability Affect Student Achievement? Journal of Applied Econometrics 18(5):527-44.

Hanushek, Eric and Alfred A. Lindseth. 2009. Schoolhouses, Courthouses, and Statehouses. New Jersey: Princeton University Press.

Hanushek, Eric, Steven Rivkin, and Lori Taylor. 1996. Aggregation and the Estimated Effects of School Resources. Review of Economics and Statistics. 78(4):611-627.

Houtenville A and K Conway. 2008. Parental Effort, School Resources and Student Achievement. Journal of Human Resources. XLIII(2):437-53. 
Krueger, Alan B. 1999. Experimental Estimates of Education Production Functions. Quarterly Journal of Economics: 497-532.

Marks, Gary N. 2008. Accounting for the gender gaps in student performance in reading and mathematics: evidence from 331 countries. Oxford Review of Education. 34(1):89-109.

McKown, Clark and Rhona S Weinstein. 2003. The Development Consequences of Stereotype Consciousness in Middle Childhood. Child Development. 74:498-515.

Murray, SE, WN Evans, and RM Schwab 1997. Education Finance Reform and the Distribution of Education Resources. American Economic Review. 88(4):789-812.

Niederle, Muriel and Lise Vesterlund. 2010. Explaining the Gender Gap in Math Test Scores: The Role of Competition. Journal of Economic Perspectives. 24(2): 129-144.

Okpala, Comfort, Amon Okpala, and Frederick Smith. 2001. Parental Involvement, Instructional Expenditures, Family Socioeconomic Attributes, and Student Achievement. Journal of Educational Research. 95(2):110-115.

Papke, Leslie E. 2008. The Effects of Changes in Michigan's School Finance System. Public Finance Review. 36(4):456-474.

Pope, Devin G and Justin R Sydnor. 2010. Geographic Variation in the Gender Differences in Test Scores. Journal of Economic Perspectives. 24(2):95-108.

Public Elementary/Secondary School Universe Survey. 1987-2002. National Center for Educational Statistics: Common Core of Data.

Rivkin, Steven, Eric Hanushek, and John Kain. 2005. Teachers, Schools, and Academic Achievement. Econometrica 73(2):417-458.

Sharp, William L. 1993. School Spending: Is There a Relationship Between Spending and Student Achievement? A Correlation Study of Illinois Schools. Presentation at the Annual Meeting of the American Education Finance Association.

Sherlock, Molly. 2011. The Effects of Financial Resources of Test Pass Rates: Evidence from Vermont's Equal Education Opportunity Act. Public Finance Review. 39(3):331-364.

Stewart, David and Joseph Panetta. 1999. West Virginia. In Public School Finance Programs of the United States and Canada 1998-99. Education Finance Statistics Center.

West Virginia Educational Statistical Summary. 1985-2002. West Virginia Department of Education.

West Virginia Report Card Educational Trends: 1985-86 through 1989-90 State Data. 1990. West Virginia Department of Education. 
West Virginia Report Cards: County-by-County Trend Data 1998-1999 Through 2002-2003. 2004. West Virginia Department of Education

West Virginia Report Cards: State, County, and School Data. 1985-2002. West Virginia Department of Education.

West Virginia Report Cards Trend Data: 1993-1994 through 1997-1998 State Data. 1999. West Virginia Department of Education.

West Virginia Report Cards Trend Data: 1994-1995 through 1998-1999 State Data. 2000. West Virginia Department of Education.

White, David. The Property Tax in West Virginia: A Review and Evaluation. <http://www.polsci.wvu.edu/ipa/par/report_8_3.html> 